\title{
Fruits Classification from Image using MPEG-7 Visual Descriptors and Extreme Learning Machine
}

\author{
Joko Siswantoro, Heru Arwoko, Muhammad Z. F. N. Siswantoro \\ Department of Informatics Engineering University of Surabaya \\ J. Kali Rungkut, Surabaya, 60293, Indonesia \\ joko_siswantoro@staff.ubaya.ac.id, heru_a@staff.ubaya.ac.id, s160417111@student.ubaya.ac.id
}

\begin{abstract}
Fruit image classification has several applications and can be used as alternative to traditionally fruit classification performed by human expert. This paper aims to propose fruits classification method from image using extreme learning machine (ELM), MPEG-7 visual descriptors, and principle component analysis (PCA). The optimum parameters of ELM and PCA were determined using grid search optimization. The best classification performance of $97.33 \%$ has been achieved in classifying Indonesian fruit images consisted of $\mathbf{1 5}$ classes. By applying the ensemble of ELMs, the classification accuracy was increased to $98.03 \%$. This result shows that the proposed method produces high classification performance.
\end{abstract}

Keywords - Indonesian fruit; fruit image; extreme learning machine; MPEG-7 visual descriptors; classification

\section{INTRODUCTION}

There are several tropical fruits grown and traded in Indonesia. Due to similarities in visual appearance, some Indonesian fruits are difficult to be recognized manually by inexpert person [1], such as Pacitan orange and Siam lime. To overcome this problem, fruits classification from image can be considered as alternative to manual fruit recognition. Fruits classification from image has various applications, such as for fruit pricing in supermarket [2], fruit sorting [3] and grading [4] in food industry, as well as fruit maturity identification [5].

Several fruits classification methods from image have been proposed in the previous studies. The methods can be categorized into two groups, fruits classification for same variety $[3]-[6]$ and fruits classification for different variety [1], [7]-[17]. Various features and classifiers have been employed in fruits image classification. In some previous studies, segmentation process was used to divide the pixels in fruit image into fruit pixels and background pixels before feature extraction process, although the image has a homogeneous background. However, this process may increase the time required for classification.

Studies in [7] and [12] have proposed fruit classification methods by extracting morphology based shape measure features, Unser's features, and color histogram from the fruit image. Split and merge algorithm was applied in segmentation process before features extraction. Since the image contains several fruit objects, the proposed method needed to determine the region in the image which only contains a fruit object to extract the shape features. This step will also increase the computation time. The dimension of extracted features was reduced using principle component analysis (PCA) before inputted to classifier. Feed forward neural network trained with various metaheuristic optimization methods was used for classification. The proposed methods were used to classify 18 classes fruit and only achieved the highest accuracy of $89.11 \%$ with 5 -folds cross validation. Study in
[10] has proposed fruit classification methods similar to the methods proposed in [7] and [12] but using wavelet entropy features extracted from every channel in RGB image. However, the accuracy of the proposed method is only $89.5 \%$.

Shape features based on the derivative of radius function and statistical color features were used in [11] and [13] to classify natural produce from image. Automatic thresholding was applied to segment fruit object and its background. The classification method in [11] used artificial neural network (ANN) and obtained accuracy of $99.87 \%$ in classifying three classes natural produce. On the other hand, the classification method in [13] used ANN combined with a linear model trained using Kalman filter [18] for classifying natural produce image consisted of 10 classes and achieved accuracy of $98.4 \%$. However, both proposed methods cannot be used to classify fruit image with more than one object.

Recently, deep neural network was also employed to classify fruit image, as reported in [9], [14]-[17]. Although deep learning model can achieve classification accuracy more than $90 \%$, it required high computer resources and high computational cost in training process [15]. Furthermore, segmentation process was still performed on the fruit image before inputted to deep neural network to achieve a good accuracy as reported in [14], [15] and [16].

Moving Picture Experts Group-7 (MPEG-7) visual descriptors [19] have been used for fruits classification from image in some study [1], [8]. MPEG-7 descriptor is a multimedia content descriptor consisted of audio and visual descriptors that can be used to describe multimedia data [20]. By using MPEG-7 visual descriptors, the classification process of fruit image does not require preprocessing and segmentation processes [8]. An image based Indonesian fruit classification method has been proposed in [8] using $k$-nearest neighbor $(k-\mathrm{NN})$ and MPEG-7 color structure descriptor. To reduce the computational complexity during training and testing processes, some features in the descriptor was excluded using variance base feature selection. The best accuracy of $90.86 \%$ was obtained in classifying seven classes fruits image.

To increase the performance of Indonesian fruits image classification, the ensemble of $k-\mathrm{NN}$ and linear discriminant analysis (LDA) trained with combination of MPEG-7 color and texture descriptors has been used in [1]. PCA was used to decrease the length of feature vector in the combination before used in classification. The best accuracy of $97.80 \%$ was achieved in classifying 15 classes Indonesian fruits image. However, the parameters of LDA and k-NN used in [1] were not optimized. 
In the previous studies, fruits image classification based on MPEG-7 visual descriptor only employed simple classifiers. Therefore, there is a possibility to increase classification accuracy by applying more complex classifiers such as extreme machine learning (ELM) [21]. ELM is a three layers feed forward neural networks. The first layer is input layer which corresponds to input features, the second layer is hidden layer, and the last is output layer which corresponds to output class. During training process, the weights and biases of ELM from the first layer to the second layer are randomly generated once and do not need to be updated. The weights of ELM from the second layer to the last layer can be easily calculated without iteration process. Furthermore, ELM has been applied to solve both prediction [22]-[24] and classification [25]-[27] problems in various field.

This paper proposes a fruit image classification method using constrained-optimization-based ELM, MPEG-7 visual descriptors and PCA. To obtain a good classification performance, the parameters of ELM and PCA were determined using grid search optimization.

\section{MATERIALS AND METHOD}

\section{A. Image data set}

The proposed method was validated using UbayaIFDS3000 data set proposed in [1]. The data set contained of 15 classes Indonesian fruits namely Star fruit, Soursop, Siam lime, Sapodilla, Salak, Pineapple, Persimmon, Pacitan orange, Mangosteen, Guava, Durian, Duku, Dragon fruit, Avocado, and Ambarella. Each class consisted of 200 images captured with the dimension of $2,592 \times 1,456$ pixels in RGB color space and saved in JPEG format.

The image had light blue, light green, light yellow, pink, and white background. It was captured using two intensities illumination sources $(1,050 \mathrm{~lm}$ and $160 \mathrm{~lm})$ with two camera orientations $\left(0^{\circ}\right.$ and $\left.45^{\circ}\right)$. To increase the complexity, the number of objects varied and there were shadows near some objects in each image. Fig. 1 shows some images in the Ubaya-IFDS3000 data set.

\section{B. Method}

The proposed fruits classification method comprised three successive processes, including features extraction, dimensional reduction, and classification. The explanations for every process are as follow.

1) Features extraction

Five MPEG-7 visual descriptors were extracted in this process. Segmentation process was not required before this process due to each image in Ubaya-IFDS3000 data set has homogenous background. Therefore, feature extraction could be directly performed in the whole image. The extracted descriptors consisted of color structure descriptor $\left(D_{1}\right)$, scalable color descriptor $\left(D_{2}\right)$, color layout descriptor $\left(D_{3}\right)$, edge histogram descriptor $\left(D_{4}\right)$ and homogeneous texture descriptor $\left(D_{5}\right)$.

Color structure descriptor is a color histogram in HMMD color space with 256 colors. It is used to describe the color distribution and the local color structure of the fruit image. Scalable color descriptor is a color histogram extracted in HSV color space with 256 color. The histogram is normalized, nonlinearly mapped into four-bit integer representation, and coded using Haar transform. Color layout descriptor is used to represent the spatial color distribution of fruit image. It is constructed by transforming 2D array of local representative color of the image, which is the average of pixel intensities in $\mathrm{YCbCr}$ color space, using discrete cosine Fourier transform (DCT). Color layout descriptor is obtained by nonlinearly quantizing some DCT coefficients in low frequency.

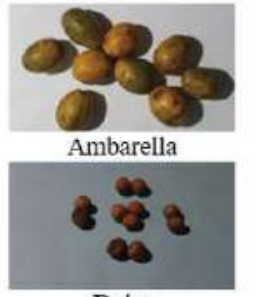

Duku

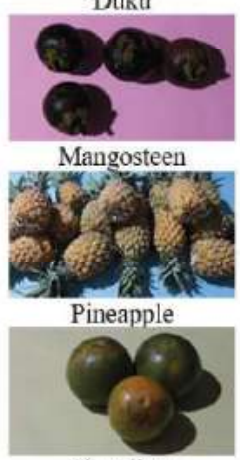

Siam lime

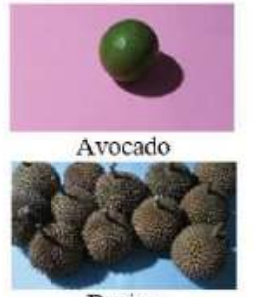

Durian

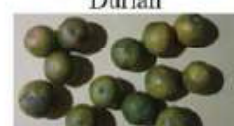

Pacitan orange

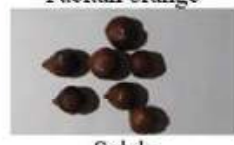

Salak

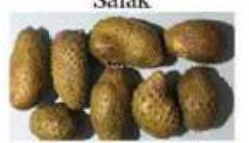

Soursop

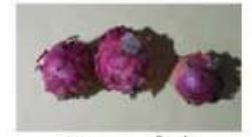

Dragon fruit

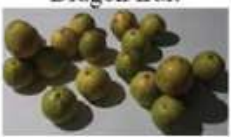

Guava

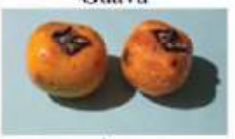

Persimmon

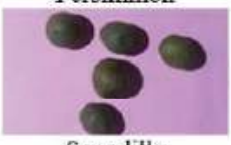

Sapodilla

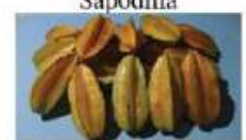

Star fruit
Fig. 1. Some fruits images in Ubaya-IFDS3000 data set

Edge histogram descriptor contains spatial edge distribution of the fruit image. The image was portioned into $4 \times 4$ nonoverlapping sub region and then the local edge distribution was extracted from every sub region. From every sub region five edge categories, including vertical, horizontal, $45^{\circ}$ diagonal, $135^{\circ}$ diagonal, and nondirectional edge, were extracted using appropriate five edge detectors. Homogeneous texture descriptor uses the mean and the deviation of energy from a set of channels in 2D frequency after transformed with Gabor filtered Fourier. The detail explanation about MPGE-7 descriptors extraction can be found in Manjunath et al. [18]. In this study the total number of extracted features was 774 , consisted of 256 features from $D_{1}, 256$ features from $D_{2}, 120$ features from $D_{3}, 80$ features from $D_{4}$ and 62 features from $D_{5}$.

The proposed method used MPEG-7 Low Level Feature Extraction Static/Dynamic Library [20] and OpenCV 2.3.1 [28] in extracting MPEG-7 visual descriptors. In this study, the combinations of descriptors used for classification were the combinations that achieve classification accuracy more than $90 \%$ in classifying Indonesian fruit image reported in [1], as tabulated in TABLE I.

\section{2) Dimensional reduction}

A huge number of features does not guarantee a classifier achieves the best performance. Moreover, this condition can also increase both complexity and computational time in classifier training process. To overcome this problem, PCA was employed to decrease the length features before classification proses [29]. PCA is categorized as unsupervised method that works by transforming the input features vector to a new vectors in another space, called principle components, using a linear transformation based on the 
eigenvectors of input features covariance matrix $\boldsymbol{\Sigma}$, as shown (1),

$$
\mathbf{X}_{p c}=(\mathbf{X}-\boldsymbol{\mu}) \mathbf{V}
$$

where $\mathbf{X}$ and $\boldsymbol{\mu}$ are the input features vector and its mean, respectively, $\mathbf{X}_{p c}$ is principle components, and $\mathbf{V}$ is the eigenvectors of $\boldsymbol{\Sigma}$.

TABLE I. THE COMBINATION OF MPEG-7 DESCRIPTORS USED FOR Classification

\begin{tabular}{|c|c|c|c|}
\hline $\boldsymbol{i}$ & $\begin{array}{c}\text { Combination } \\
\text { of Descriptors } \\
\left(\boldsymbol{C}_{\boldsymbol{i}}\right)\end{array}$ & $\boldsymbol{i}$ & $\begin{array}{c}\text { Combination of } \\
\text { Descriptors }\left(\boldsymbol{C}_{\boldsymbol{i}}\right)\end{array}$ \\
\hline 1 & $D_{1}$ & 13 & $D_{1}, D_{3}, D_{4}$ \\
\hline 2 & $D_{2}$ & 14 & $D_{1}, D_{3}, D_{5}$ \\
\hline 3 & $D_{1}, D_{2}$ & 15 & $D_{1}, D_{4}, D_{5}$ \\
\hline 4 & $D_{1}, D_{3}$ & 16 & $D_{2}, D_{3}, D_{4}$ \\
\hline 5 & $D_{1}, D_{4}$ & 17 & $D_{2}, D_{3}, D_{5}$ \\
\hline 6 & $D_{1}, D_{5}$ & 18 & $D_{2}, D_{4}, D_{5}$ \\
\hline 7 & $D_{2}, D_{3}$ & 19 & $D_{1}, D_{2}, D_{3}, D_{4}$ \\
\hline 8 & $D_{2}, D_{4}$ & 20 & $D_{1}, D_{2}, D_{3}, D_{5}$ \\
\hline 9 & $D_{2}, D_{5}$ & 21 & $D_{1}, D_{2}, D_{4}, D_{5}$ \\
\hline 10 & $D_{1}, D_{2}, D_{3}$ & 22 & $D_{1}, D_{3}, D_{4}, D_{5}$ \\
\hline 11 & $D_{1}, D_{2}, D_{4}$ & 23 & $D_{2}, D_{3}, D_{4}, D_{5}$ \\
\hline 12 & $D_{1}, D_{2}, D_{5}$ & 24 & $D_{1}, D_{2}, D_{3}, D_{4}, D_{5}$ \\
\hline
\end{tabular}

After transformation, all principle components are ordered based on the order of eigenvalues of $\boldsymbol{\Sigma}$ in decreasing order and are not correlated with each other. To perform dimensional reduction, PCA selects some first few principle components as reduced features while maintaining the variability of the input features. To guarantee there is no domination from some features to the others, each reduced feature was then scaled to the range $[0,1]$. The following equation was used to transform each reduced feature to the range $[0,1]$,

$$
x_{s}=\frac{x_{r}-\operatorname{minimum}\left(x_{r}\right)}{\operatorname{maximum}\left(x_{r}\right)-\operatorname{minimum}\left(x_{r}\right)}
$$

where $x_{r}$ and $x_{s}$ are reduced and scaled features, respectively

The dimension of reduced features used in classification was determined such that the proportion of the variation that needs to be explained is greater than $p$ for some value $p$. The value of $p$ was determined using grid search optimization in the range $[0.88,0.99]$ with increment 0.01 . In this study, dimensional reduction using PCA was performed using scikitlearn 0.20 .3 library [30].

\section{3) Classification}

This study employed constrained-optimization-based ELM [21] to classify Indonesian fruit image using the combination of MPEG-7 color and texture descriptor as input features. The output of ELM is obtained by multiplying the second layer output $\mathbf{g}(\mathbf{x})=\left[g_{1}(\mathbf{x}), g_{2}(\mathbf{x}), \ldots, g_{n}(\mathbf{x})\right]$ with respect to input $\mathbf{x}=\left[x_{1}, x, \ldots, x_{m}\right]$ and the weight from the second layer to the last layer $\boldsymbol{\beta}=\left[\beta_{1}, \beta_{2}, \ldots, \beta_{n}\right]^{T}$ as in the following equation,

$$
\mathbf{f}(\mathbf{x})=\mathbf{g}(\mathbf{x}) \boldsymbol{\beta}
$$

where $m$ and $n$ are the dimension of input and the number of nodes in the second layer, respectively.
ELM training aims to determine the output weight $\beta$ that minimizes the ELM output error and the norm of $\beta$ as formulated in the following equation,

$$
\text { Minimize: }\|\mathbf{G} \boldsymbol{\beta}-\mathbf{Y}\| \text { and }\|\boldsymbol{\beta}\|
$$

where $\mathbf{G}$ is the second layer output matrix for all training data,

$$
\mathbf{G}=\left[\begin{array}{c}
\mathbf{g}\left(\mathbf{x}_{1}\right) \\
\mathbf{g}\left(\mathbf{x}_{2}\right) \\
\vdots \\
\mathbf{g}\left(\mathbf{x}_{N}\right)
\end{array}\right]=\left[\begin{array}{cccc}
g_{1}\left(\mathbf{x}_{1}\right) & g_{2}\left(\mathbf{x}_{1}\right) & \cdots & g_{n}\left(\mathbf{x}_{1}\right) \\
g_{1}\left(\mathbf{x}_{2}\right) & g_{2}\left(\mathbf{x}_{2}\right) & \cdots & g_{n}\left(\mathbf{x}_{2}\right) \\
\vdots & \vdots & \ddots & \vdots \\
g_{1}\left(\mathbf{x}_{N}\right) & g_{2}\left(\mathbf{x}_{N}\right) & \cdots & g\left(\mathbf{x}_{N}\right)
\end{array}\right]
$$

$\mathbf{Y}=\left[\mathbf{y}_{1}^{T}, \mathbf{y}_{2}^{T}, \ldots, \mathbf{y}_{N}^{T}\right]$ is the expected output matrix for all training data, $\mathbf{y}_{i}=\left[y_{i 1}, y_{i 2}, \ldots, y_{i k}\right]^{T}, i=1,2, \ldots, N, N$ is the number of training data and $k$ is the dimension of ELM output. In classification problem the value of $y_{i j}, j=1,2, \ldots, k$, is defined as in $(6)$

$$
y_{i j}=\left\{\begin{array}{l}
1, i^{\text {th }} \text { training data belongs to } j^{\text {th }} \text { class } \\
0, \text { otherwise. }
\end{array}\right.
$$

The optimization problem in (4) can be formulated as a constrained optimization problem,

$$
\begin{aligned}
& \text { Minimize: } L=\frac{1}{2}\|\boldsymbol{\beta}\|^{2}+\frac{1}{2} C \sum_{i=1}^{N}\left\|\boldsymbol{\varepsilon}_{i}\right\|^{2} \\
& \text { Subject to: } \mathbf{g}\left(\mathbf{x}_{i}\right) \boldsymbol{\beta}=\mathbf{y}_{i}^{T}-\boldsymbol{\varepsilon}_{i}^{T}, i=1,2, \ldots, N
\end{aligned}
$$

where $\varepsilon_{i}$ is the ELM output error for $i^{\text {th }}$ training data and $C$ is a user specified parameter. By applying the Karush-KuhnTucker (KKT) theorem [31] the solution of the optimization problem in (7) are as follow:

- If $N<n$, then

$$
\boldsymbol{\beta}=\mathbf{G}^{T}\left(\frac{1}{C} \mathbf{I}+\mathbf{G G}^{T}\right)^{-1} \mathbf{Y}
$$

and the output of ELM is

$$
\mathbf{f}(\mathbf{x})=\mathbf{g}(\mathbf{x}) \mathbf{G}\left(\frac{1}{C} \mathbf{I}+\mathbf{G G}^{T}\right)^{-1} \mathbf{Y} .
$$

- If $N>n$, then

$$
\boldsymbol{\beta}=\left(\frac{1}{C} \mathbf{I}+\mathbf{G}^{T} \mathbf{G}\right)^{-1} \mathbf{G}^{T} \mathbf{Y}
$$

and the output of ELM is

$$
\mathbf{f}(\mathbf{x})=\mathbf{g}(\mathbf{x})\left(\frac{1}{C} \mathbf{I}+\mathbf{G}^{T} \mathbf{G}\right)^{-1} \mathbf{G}^{T} \mathbf{Y}
$$

The predicted class label for an unknown data $\mathbf{x}_{u}$ is defined as the index of $\mathbf{f}\left(\mathbf{x}_{u}\right)=\left[f_{1}\left(\mathbf{x}_{u}\right), f_{2}\left(\mathbf{x}_{u}\right), \ldots, f_{k}\left(\mathbf{x}_{u}\right)\right]^{T}$ that has highest value of $f_{i}\left(\mathbf{x}_{u}\right)$ for some $i \in[1, k]$. Therefore, the predicted class label for $\mathbf{x}_{u}$ can be determined using the following equation

$$
\operatorname{class}\left(\mathbf{x}_{u}\right)=\underset{i \in[1, k]}{\operatorname{argmax}} f_{i}\left(\mathbf{x}_{u}\right) .
$$


A sigmoid function, as in (13), was employed as transfer function from the first layer to the second layer of ELM.

$$
S(x)=\frac{1}{1+e^{-x}} .
$$

Suppose $\mathbf{w}_{i}$ and $b_{i}, i=12, \ldots, n$ are the weight and bias, respectively, from the firs layer to $i^{\text {th }}$ node in the second layer of ELM. In this study, $\mathbf{w}_{i}$ and $b_{i}, i=12, \ldots, n$ were randomly generated from normal standard distribution $\mathrm{N}(0,1)$. Therefore, the output of the second layer of ELM was

$\mathbf{g}(\mathbf{x})=\left[S\left(\mathbf{w}_{1}^{T} \mathbf{x}+b_{1}\right), S\left(\mathbf{w}_{2}^{T} \mathbf{x}+b_{2}\right), \ldots, S\left(\mathbf{w}_{n}^{T} \mathbf{x}+b_{n}\right)\right]$.

According to Huang, et al. [20] the classification performance of ELM depend on the value $C$ and $n$. Therefore, this study employed grid search optimization to obtain the optimum values of $C$ and $n$ together with the optimum value of principle component. The values of $C$ and $n$ were chosen from the range $\left\{2^{5}, 2^{10}, 2^{15}, \ldots, 2^{25}\right\}$ and $\{400,410,420, \ldots, 1000\}$, respectively. The proposed method implemented ELM in Python language programing using scikit-learn 0.20.3 [30], NumPy 1.16.2 [32], and SciPy 1.2.1 [33] libraries.

\section{Validation}

Ubaya-IFDS3000 data set was divided into two disjoint subsets using stratified random sub sampling without replacement [34], with ratio 50:50 to validate the proposed method. The first subset was used as training data and the second as testing data. Five pairs of such subset were created to measure the accuracy of ELM.

ELM was trained using each training data with various parameter values for PCA and ELM provided by grid search optimization. The performance of the trained ELM was then measured by calculating the classification accuracy for the respective testing data using the following equation,

$$
a c c_{i}=\frac{N c_{i}}{N_{i}} \times 100 \%
$$

where $a c c_{i}$ is the classification accuracy of ELM in the $i^{\text {th }}$ testing data set, $i=12, \ldots, 5, N c_{i}$ and $N_{i}$ are the number of correctly classified image and the number of image, respectively, in the $i^{\text {th }}$ testing data set. The mean of classification accuracies was used to determine the optimal parameters for PCA and ELM and the performance of ELM.

\section{RESULTS AND DISCUSSION}

The optimum parameters of PCA and ELM resulted from grid search optimization is tabulated in TABLE II. From TABLE II, it can be observed that the optimum parameter values varied between one combination of MPEG-7 descriptors and others. However, there were some combinations of MPEG-7 descriptors using same parameter values, such as $p=0.89$ used in 10 combinations, $n=940$ and $n=1000$ used in five combinations, and $C=2^{5}$ and $C=2^{10}$ used in 10 and 14 combinations, respectively.

The classification accuracies of ELM using 24 combinations of MPEG-7 descriptors are summarized in TABLE III. The table also provide the summary of classification accuracies for $\mathrm{k}-\mathrm{NN}$ and LDA reported [1]. From TABLE III, it can be seen that ELM achieved the best classification accuracy of $97.33 \% \pm 0.33 \%$ by using $C_{9}$ as input features, followed by $C_{10} \quad(97.28 \% \pm 0.34 \%)$ and
$C_{12}(97.23 \% \pm 0.30 \%)$. From 24 combinations of descriptors, ELM achieved accuracy greater than $97 \%$ for 10 combinations, greater than $96 \%$ but less than $97 \%$ for 10 combinations, and between $94 \%$ and $96 \%$ for the rest. Furthermore, the classification accuracy of ELM had small standard deviation, between $0.14 \%$ and $0.60 \%$. These results show that ELM achieves a good classification performance with small variation among different testing data set.

\begin{tabular}{|c|c|c|c|c|c|c|c|}
\hline \multirow[t]{3}{*}{$C_{l}$} & \multicolumn{3}{|c|}{$\begin{array}{l}\text { Optimum } \\
\text { Parameters }\end{array}$} & \multirow[t]{3}{*}{$C_{t}$} & \multicolumn{3}{|c|}{$\begin{array}{c}\text { Optimum } \\
\text { Parameters }\end{array}$} \\
\hline & \multirow{2}{*}{$\frac{P C A}{p}$} & \multicolumn{2}{|c|}{ ELM } & & \multirow{2}{*}{$\frac{P C A}{p}$} & \multicolumn{2}{|c|}{ ELM } \\
\hline & & $n$ & $C$ & & & $N$ & $C$ \\
\hline$C_{1}$ & 0.88 & 940 & $2^{10}$ & $C_{13}$ & 0.89 & 1000 & $2^{10}$ \\
\hline$C_{2}$ & 0.99 & 930 & $2^{5}$ & $C_{14}$ & 0.89 & 920 & $2^{10}$ \\
\hline$C_{3}$ & 0.89 & 940 & $2^{10}$ & $C_{15}$ & 0.89 & 1000 & $2^{10}$ \\
\hline$C_{4}$ & 0.89 & 920 & $2^{10}$ & $C_{16}$ & 0.98 & 1000 & $2^{5}$ \\
\hline$C_{5}$ & 0.92 & 870 & $2^{5}$ & $C_{17}$ & 0.97 & 960 & $2^{5}$ \\
\hline$C_{6}$ & 0.89 & 940 & $2^{10}$ & $C_{18}$ & 0.98 & 970 & $2^{5}$ \\
\hline$C_{7}$ & 0.98 & 1000 & $2^{5}$ & $C_{19}$ & 0.89 & 990 & $2^{10}$ \\
\hline$C_{8}$ & 0.99 & 910 & $2^{5}$ & $C_{20}$ & 0.89 & 930 & $2^{10}$ \\
\hline$C_{9}$ & 0.98 & 920 & $2^{5}$ & $C_{21}$ & 0.88 & 970 & $2^{10}$ \\
\hline$C_{10}$ & 0.88 & 940 & $2^{10}$ & $C_{22}$ & 0.89 & 1000 & $2^{10}$ \\
\hline$c_{11}$ & 0.88 & 970 & $2^{10}$ & $C_{23}$ & 0.98 & 980 & $2^{5}$ \\
\hline$C_{12}$ & 0.89 & 940 & $2^{10}$ & $C_{24}$ & 0.91 & 960 & $2^{5}$ \\
\hline
\end{tabular}

TABLE II. THE OPTIMUM PARAMETERS OF PCA AND ELM

TABLE III. ClasSIFICATION PERFORMANCE COMPARISON OF K-NN,

\begin{tabular}{|c|c|c|c|}
\hline \multirow[t]{2}{*}{$c_{i}$} & \multicolumn{3}{|c|}{ Accuracy $(\%)$} \\
\hline & $k-N \boldsymbol{N}[1]$ & $L D A[1]$ & $E L M$ \\
\hline$C_{1}$ & $92.69 \pm 0.52$ & $92.83 \pm 0.63$ & $97.04 \pm 0.31$ \\
\hline$C_{2}$ & $96.09 \pm 0.33$ & $95.23 \pm 0.49$ & $97.09 \pm 0.23$ \\
\hline$C_{3}$ & $93.08 \pm 0.47$ & $95.96 \pm 0.14$ & $97.21 \pm 0.26$ \\
\hline$C_{4}$ & $92.83 \pm 0.43$ & $94.07 \pm 0.42$ & $97.09 \pm 0.26$ \\
\hline$C_{5}$ & $92.41 \pm 0.87$ & $92.96 \pm 0.54$ & $96.37 \pm 0.29$ \\
\hline$C_{6}$ & $92.73 \pm 0.53$ & $93.89 \pm 0.84$ & $97.19 \pm 0.14$ \\
\hline$C_{7}$ & $96.28 \pm 0.37$ & $96.13 \pm 0.20$ & $96.95 \pm 0.43$ \\
\hline$C_{8}$ & $94.55 \pm 0.58$ & $94.92 \pm 0.45$ & $94.83 \pm 0.37$ \\
\hline$C_{9}$ & $95.67 \pm 0.47$ & $96.05 \pm 0.50$ & $97.33 \pm 0.33$ \\
\hline$C_{10}$ & $93.39 \pm 0.56$ & $96.23 \pm 0.23$ & $97.28 \pm 0.34$ \\
\hline$C_{11}$ & $92.97 \pm 0.44$ & $95.57 \pm 0.30$ & $96.73 \pm 0.22$ \\
\hline$C_{12}$ & $93.17 \pm 0.37$ & $96.32 \pm 0.41$ & $97.23 \pm 0.30$ \\
\hline$C_{13}$ & $92.43 \pm 0.88$ & $93.79 \pm 0.54$ & $96.51 \pm 0.51$ \\
\hline$C_{14}$ & $92.84 \pm 0.44$ & $94.42 \pm 0.36$ & $97.08 \pm 0.19$ \\
\hline$C_{15}$ & $92.43 \pm 0.50$ & $93.87 \pm 0.58$ & $96.57 \pm 0.49$ \\
\hline$C_{16}$ & $94.65 \pm 0.53$ & $95.61 \pm 0.32$ & $95.00 \pm 0.19$ \\
\hline$C_{17}$ & $96.09 \pm 0.67$ & $96.57 \pm 0.29$ & $96.89 \pm 0.35$ \\
\hline$C_{18}$ & $94.44 \pm 0.28$ & $95.65 \pm 0.44$ & $95.15 \pm 0.20$ \\
\hline$C_{19}$ & $92.92 \pm 0.59$ & $95.96 \pm 0.19$ & $96.71 \pm 0.47$ \\
\hline$C_{20}$ & $93.28 \pm 0.56$ & $96.45 \pm 0.46$ & $97.20 \pm 0.42$ \\
\hline$C_{21}$ & $93.05 \pm 0.45$ & $95.97 \pm 0.44$ & $96.73 \pm 0.25$ \\
\hline$C_{22}$ & $92.44 \pm 0.54$ & $94.09 \pm 0.69$ & $96.55 \pm 0.60$ \\
\hline$C_{23}$ & $94.95 \pm 0.44$ & $96.49 \pm 0.32$ & $94.71 \pm 0.51$ \\
\hline$C_{24}$ & $92.92 \pm 0.38$ & $96.03 \pm 0.46$ & $96.80 \pm 0.55$ \\
\hline
\end{tabular}
LDA, AND ELM USING SOME COMBINATIONS OF MPEG-7 DESCRIPTORS

In comparison with $k$-NN and LDA, ELM achieved better classification performance compared to $k-\mathrm{NN}$ and LDA for almost all combination of MPEG-7 descriptors, as shown in TABLE III. However, the best performance of $k$-NN and LDA, which are $96.28 \%$ and $96.57 \%$, resp., were still less than the best classification performance of ELM. This result show that ELM outperforms k-NN and LDA. From TABLE III, it can also be observed that more descriptors in the combination did not guarantee improve the performance of ELM. This phenomenon was also occurred in $k-\mathrm{NN}$ and LDA as reported in [1]. 
To increase the classification accuracy, study in [1] has proposed an ensemble of $k$-NN and LDA and obtained the best classification accuracy of $97.80 \pm 0.28 \%$. The same approach was also performed in this study to increase the classification accuracy of ELM. Three ELMs which have highest classification accuracy were used as based classifier for the ensemble and obtained the classification accuracy of $98.03 \% \pm 0.36 \%$. This result show that the ensemble of ELM outperforms the ensemble of $k$-NN and LDA.

Furthermore, the performance of the combination descriptors used in this study was compared with statistical color features, color histogram and Unser's features. The segmentation process was performed to the fruit image before extracting the features. The classification accuracy of ELM with statistical color features, color histogram and Unser's features as input features together with the optimum parameters are shown in TABLE IV. From TABLE III and TABLE IV, it can be observed that the combination of MPEG-7 visual descriptors is more discriminative compared to statistical color features, color histogram and Unser's features when used as input features to ELM.

TABLE IV. Classification PERFormance ELM USING STATISTICAL COLOR FEATURES, COLOR HISTOGRAM AND UNSER'S FEATURES

\begin{tabular}{|l|c|c|c|c|}
\hline \multirow{3}{*}{ Features } & \multicolumn{3}{|c|}{$\begin{array}{c}\text { Optimum } \\
\text { Parameters }\end{array}$} & \multirow{3}{*}{ Accuracy (\%) } \\
\cline { 2 - 4 } & $\boldsymbol{P C A}$ & \multicolumn{2}{|c|}{$\boldsymbol{E L M}$} & \\
\cline { 2 - 4 } & $p$ & $n$ & $\boldsymbol{C}$ & \\
\hline Statistical color features & 0.99 & 940 & $2^{15}$ & $76.88 \pm 0.86$ \\
\hline Color histogram & 0.99 & 670 & $2^{15}$ & $80.05 \pm 0.80$ \\
\hline Unser's features & 0.92 & 970 & $2^{10}$ & $62.72 \pm 1.19$ \\
\hline
\end{tabular}

The proposed method was implemented on a machine with processor Intel ${ }^{\circledR}$ Core $^{\mathrm{TM}}$ i7-8550U and 20 GB RAM. The computational time needed to train the proposed classification method varied between 2.21 seconds to 2.69 seconds depending on the number of nodes in the second layer of ELM and the number of principle components used in PCA. Furthermore, the proposed method only needed about $67.8 \mathrm{~ms}$ to classify a fruit image. However, grid search optimization required high computational time in determined optimum PCA and ELM parameters. On average grid search optimization took 7929 seconds to determine optimum parameter from 3960 possible values.

\section{CONCLUSION}

This study proposed Indonesian fruits classification method from image. The method used constrainedoptimization-based ELM as classifier and the combination of MPEG-7 visual descriptors. PCA was used to decrease the length of input features based on the proportion of the variation of original features that needs to be explained. The user specified parameters for PCA and ELM were optimized using grid search optimization such that the best classification performance is achieved. The proposed method has been evaluated using 3000 fruit images from Ubaya-IFDS3000 data set and obtained the best classification accuracy of $97.33 \% \pm 0.33 \%$. Furthermore, the experiment result also shows that ELM outperforms $k$-NN and LDA. For feature work, the using of other optimization method need to be considered to reduce the computational time in determining optimum PCA and ELM parameters.

\section{ACKNOWLEDGMENT}

The authors would like to thank Kemenristek/BRIN Republic of Indonesia and University of Surabaya for providing financial support and facilities under PDUPT Grant No. 018/SP-Lit/LPPM-01/RistekBRIN/Multi/FT/III/2020.

\section{REFERENCES}

[1] J. Siswantoro, H. Arwoko, and M. Widiasri, "Indonesian fruits classification from image using MPEG-7 descriptors and ensemble of simple classifiers," J. Food Process Eng., vol. 43, no, 7, pp. 1-13, 2020, doi: 10.1111 /jfpe. 13414 .

[2] A. Rocha, D. C. Hauagge, J. Wainer, and S. Goldenstein, "Automatic fruit and vegetable classification from images," Comput. Electron. Agric., vol. 70, no. 1, pp. 96-104. 2010, doi: http://dx.doi.org/10.1016/j.compag,2009,09.002.

[3] T.-T. Le, C.-Y. Lin, and E. Piedad Jr., "Deep learning for noninvasive classification of clustered horticultural crops - A case for banana fruit tiers," Posthanest Biol. Technol., vol. 156, p. $110922,2019$.

[4] M. P. Arakeri, "Computer vision based fruit grading system for quality evaluation of tomato in agriculture industry," Procedia Comput. Sci., vol. 79 , pp. $426-433,2016$.

[5] Y. Jiang, B. Bian, X. Wang, S. Chen, Y. Li, and Y. Sun, "Identification of tomato maturity based on multinomial logistic regression with kemel clustering by integrating color moments and physicochemical indices," J. Food Process Eng., p. el3504.

[6] K. Kheiralipour and A. Pormah. "Introducing new shape features for classification of cucumber fruit based on image processing technique and artificial neural networks," J. Food Process Eng., vol. 40, no. 6, p. e12558, 2017.

[7] Y. Zhang, S. Wang, G. Ji, and P. Phillips, "Fruit classification using computer vision and feedforward neural network," J. Food Eng., vol. 143, pp. 167-177, 2014.

[8] J. Siswantoro, H. Arwoko, and M. Widiasri, "Image Based Indonesian Fruit Recognition using MPEG-7 Color Structure Descriptor and kNearest Neighbor," in Intemational Conference on Informatics. Technology, and Engineering 2019 (InCITE 2019), 2019, p. D-84-D90.

[9] J. Steinbrener, K. Posch, and R. Leitner, "Hyperspectral fruit and vegetable classification using convolutional neural networks," Comput. Electron. Agric,, vol. 162, pp. 364-372, 2019.

[10] S. Wang. Y. Zhang, G. Ji, J. Yang, J. Wu, and L. Wei, "Fruit classification by wavelet-entropy and feedforward neural network trained by fitness-scaled chaotic $\mathrm{ABC}$ and biogeography-based optimization," Entropy, vol. 17, no. 8, pp. 5711-5728, 2015.

[11] A. S. Prabuwono, J. Siswantoro, and A. Abdullah, "Natural Produce Classification Using Computer Vision Based on Statistical Color Features and Derivative of Radius Function," Appl, Mech. Mater, vol. 771 , pp. 242-247, 2015.

[12] Y. Zhang, P. Phillips, S. Wang, G. Ji, J. Yang, and J. Wu, "Fruit classification by biogeography-based optimization and feedforward neural network," Expert Syst., vol. 33, no. 3, pp. 239-253, 2016.

[13] J. Siswantoro, A. S. Prabuwono, A. Abdullah, and B. Indrus, "Hybrid neural network and linear model for natural produce recognition using computer vision," J. ICT Res. Appl., vol. 11, no. 2, 2017, doi: 10.5614/itbj.ict.res.appl.2017.11.2.5.

[14] S.-H. Wang and Y. Chen, "Fruit category classification via an eightlayer convolutional neural network with parametric rectified linear unit and dropout technique," Multimed. Tools Appl, pp. 1-17, 2018.

[15] Y.-D. Zhang et al., "Image based fruit category classification by 13 layer deep convolutional neural network and data augmentation," Multimed. Tools Appl., vol. 78, no. 3, pp. 3613-3632, 2019.

[16] R. Katarzyna and M. Pawet, "A Vision-Based Method Utilizing Deep Convolutional Neural Networks for Fruit Variety Classification in Uncertainty Conditions of Retail Sales," Appl. Sci., vol. 9, no. 19, p. $3971,2019$.

[17] R. A. Razali and Z. Ibrahim, "Comparing bags of features, conventional convolutional neural network and AlexNet for fruit recognition," Indones, J. Electr. Eng. Comput. Sci, vol. 14, no. 1, pp. $333-339,2019$.

[18] J. Siswantoro, A. S. Prabuwono, A. Abdullah, and B. Idrus, "A linear model based on Kalman filter for improving neural network 
classification performance," Expert Syst. Appl., vol. 49, 2016, doi: 10.1016/j.eswa.2015.12.012.

[19] B. S. Manjunath, P. Salembier, and T. Sikora, Introduction to MPEG7: multimedia content description interface. John Wiley \& Sons, 2002.

[20] M. Bastan, H. Cam, U. Gudukbay, and O. Ulusoy, "Bilvideo-7: an MPEG-7- compatible video indexing and retrieval system," MultiMedia, IEEE, vol. 17, no. 3, pp. 62-73, 2010.

[21] G. Huang, H. Zhou, X. Ding, and R. Zhang, "Extreme Learning Machine for Regression and Multiclass Classification," IEEE Trans. Syst. Man, Cybern. Part B, vol. 42, no. 2, pp. 513-529, 2012, doi: 10.1109/TSMCB.2011.2168604

[22] S. Salcedo-Sanz, C. Casanova-Mateo, A. Pastor-Sánchez, and M. Sánchez-Girón, "Daily global solar radiation prediction based on a hybrid Coral Reefs Optimization-Extreme Learning Machine approach," Sol. Energy, vol. 105, pp. 91-98, 2014.

[23] Z. M. Yaseen et al., "Predicting compressive strength of lightweight foamed concrete using extreme learning machine model," Adv. Eng. Softw., vol. 115, pp. 112-125, 2018.

[24] A. S. Silitonga et al., "Biodiesel synthesis from Ceiba pentandra oil by microwave irradiation-assisted transesterification: ELM modeling and optimization," Renew. Energy, vol. 146, pp. 1278-1291, Feb. 2020, doi: 10.1016/j.renene.2019.07.065.

[25] Z. Huang, Y. Yu, J. Gu, and H. Liu, "An efficient method for traffic sign recognition based on extreme learning machine," IEEE Trans. Cybern., vol. 47 , no. 4 , pp. $920-933,2016$

[26] C. Zhu et al., "Retinal vessel segmentation in colour fundus images using Extreme Learning Machine," Comput. Med. Imaging Graph., vol. 55, pp. 68-77, 2017.

[27] S. Haidong, J. Hongkai, L. Xingqiu, and W. Shuaipeng, "Intelligent fault diagnosis of rolling bearing using deep wavelet auto-encoder with extreme learning machine," Knowledge-Based Syst., vol. 140, pp. 1 $14,2018$.

[28] G. Bradski, "The openev library," Dr Dobb's J. Softw. Tools, vol. 25 , pp. $120-125,2000$.

[29] W. K. Härdle and L. Simar, Applied Multivariate Statistical Analysis, 2nd ed. Berlin Heidelberg: Springer, 2007.

[30] F. Pedregosa et al., "Scikit-learn: Machine learning in Python," $J$. Mach. Leam. Res., vol. 12, pp. 2825-2830, 2011.

[31] R. Fletcher, Practical Methods of Optimization: Volume 2 Constrained Optimization. New York: John Wiley \& Sons, 1981.

[32] T. E. Oliphant, A guide to NumPy, vol. 1. Trelgol Publishing USA. 2006.

[33] P. Virtanen et al., "SciPy 1.0: fundamental algorithms for scientific computing in Python," Nat. Methods, vol. 17, no. 3, pp. 261-272, 2020.

[34] E. Alpaydin, Introduction to machine learning, 2nd ed. Cambridge, Massachusetts: MIT Press, 2010. 

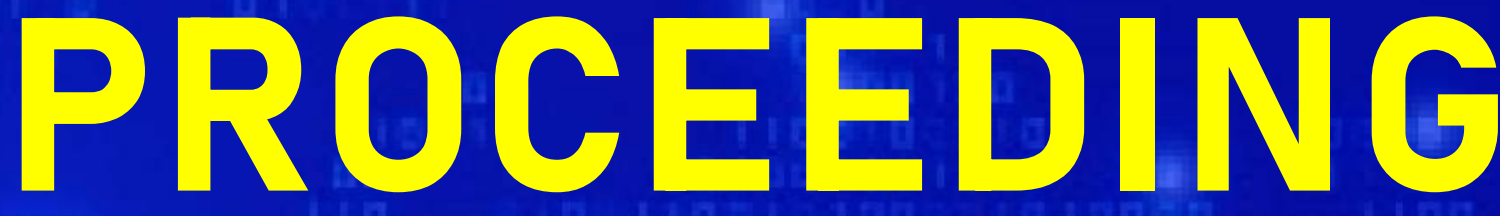

\section{\#3rd}

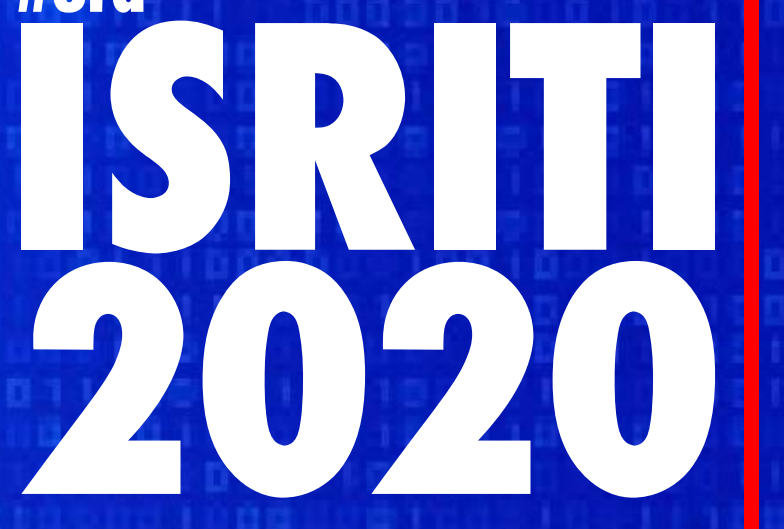

Yogyalarta - Indonesia 10 December 2020

ARTIFICIAL INTELLIGENCE for SOCIAL INTERACTIONS

isriti.akakom.ac.id 
$20203^{\text {rd }}$ International Seminar on Research of Information Technology and Intelligent Systems (ISRITI) took place 10 December 2020 in Yogyakarta, Indonesia (2)

IEEE catalog number:

CFP20AAH-PRT

ISBN:

978-1-7281-8404-3

Copyright and Reprint Permission: Abstracting is permitted with credit to the source Libraries are permitted to photocopy beyond the limit of U.S. copyright law for private use of patrons those articles in this volume that carry a code at the bottom of the first page, provided the per-copy fee indicated in the code is paid through Copyright Clearance Center, 222 Rosewood Drive, Danvers, MA 01923. For other copying, reprint or republication permission, write to IEEE Copyrights Manager, IEEE Operations Center, 445 Hoes Lane, Piscataway, NJ 08854. All rights reserved. Copyright (C) 2020 by IEEE. 


\section{International Seminar on Research of Information Technology and Intelligent Systems}

\section{The $3^{\text {rd }}$ ISRITI 2020}

10 December 2020

STMIK AKAKOM YOGYAKARTA

Jalan Raya Janti no 143, Karang Jambe, Banguntapan, Bantul Yogyakarta, Indonesia 55198

Phone: +ㅁ2 858-4813-5411 (whatsapp only) | Email: isriti@akakom.ac.id

www.isriti.akakom.ac.id 


\title{
WELCOME SPEECH FROM THE CHAIRMAN OF STMIK AKAKOM YOGYAKARTA
}

\author{
The honourable \\ Keynote Speakers (Dr. Zoohan Gani from Victoria University and Assc. Prof. Ahmad \\ Hoirul Basory from King Abdul Azis University) \\ Chairman of Widya Bakti Foundation and his staffs, \\ Representatives from IEEE Indonesia Chapter and Central IEEE, \\ Team of Indonesia Researcher and Scientist Institute, \\ Researchers and conference attendees, \\ Ladies and Gentlemen,
}

Assalamu'alaikum Wr. Wb.

May peace and health be upon us all.

First of all, let us express our utmost gratitude to God Almighty (SWT) for His blessings and grace so that even though in this coronavirus pandemic atmosphere, we can all still participate in the third iSriti international conference. On this occasion, let me express my sincere appreciation to the Keynote Speakers: Dr. Zoohan Gani from Victoria University, Sydney Australia, and Assoc. Prof. Dr. Ahmad Hoirul Basory from King Abdul Azis University, Rabig, Makkah, Saudi Arabia for their willingness to share their brilliant ideas and insights to be presented at this conference.

Dear ladies and gentlemen

On this occasion, as the head of STMIK AKAKOM Yogyakarta, I am saddened to state that the third iSriti conference had to be held online, considering that the coronavirus pandemic has not ended. Even though a pandemic currently hits us, the researchers' enthusiasm is apparent in the number of research articles submitted. We received up to 262 articles from 17 countries. Around 135 articles were accepted to be readily presented online in a conference forum with the theme: Artificial Intelligence for Social Interactions.

As the organizers of iSriti, we are very proud and grateful for the researchers' participation who have been willing to submit their research results to be published in this conference forum. We would also like to thank IEEE and IRSI, who have trusted and supported this conference from the very beginning. We still hope to build networks and information exchange between academics, practitioners, researchers, and the government to identify and explore issues, opportunities, and solutions to face challenges in the current era of technological disruption.

Finally, on this occasion, I would like to express my utmost gratitude to:

1) The distinguished keynote speakers who have been willing to share their valuable knowledge in this conference;

2) The third iSriti researchers who have presented and will present their research results;

3) Reviewers who have carefully reviewed the articles of the researchers;

4) Moderators who are more than willing to lead the plenary session;

5) IEEE for trusting us to hold this international conference;

6) IRSI, which has supported the third iSriti activities until now;

7) The committee that has been working hard to prepare this international conference according to plan; Last but not least, as the organizer, I would like to sincerely apologize for any shortcomings or inconveniences during this event.

Thank you very much for your kind attention, and Wassalamu'alaium $W r . W b$.

Yogyakarta, 10 December 2020

The Chairman of STMIK AKAKOM Yogyakarta

Totok Suprawoto, M.M., M.T. 


\section{WELCOME SPEECH FROM THE GENERAL CHAIR OF THE $3^{\text {rd }}$ ISRITI 2020}

Dear colleagues and friends.

On behalf of the organizing committee, I am delighted to welcome all participants to the 3rd International Seminar on Research of Information Technology and Intelligent Systems (ISRITI 2020). This conference is the third international conference held by STMIK Akakom Yogyakarta, Indonesia and the first to be held by STMIK Akakom in virtual form on December 10th, 2020.

In this conference, the committee decided to choose the following theme: "Artificial Intelligence for Social Interactions". This highlight was chosen because various advances in the field of AI have recently raised concerns that AI will replace various things that are the human domain. For us, AI can be used to better understand social interactions and to build machines that work more collaboratively and effectively with humans. Therefore, by highlighting that theme in ISRITI 2020, we hope we can raise awareness towards AI for social interactions.

The aim of the conference is to provide an interactive international forum for sharing and exchanging information on the latest research in the area of information technology, computer sciences, informatics, and related fields. Nearly 135 academicians, researchers, practitioners, and presenters from 17 countries (Indonesia, Malaysia, India, USA, Brazil, Australia, South Korea, Hungary, Morocco, Vietnam, Iraq, China, Thailand, Turkey, Ireland, Romania, Russia, and Saudi Arabia) gathered in this event. In total, there are 262 active papers submitted to this conference. Each paper has been reviewed with tight criteria from our invited reviewers. Based on the review result, 135 papers have been accepted, which lead to an acceptance rate of $51.5 \%$. This conference will not be successful without extensive effort from many parties. First, I would like to thank all keynote speakers for allocating their valuable time to share their knowledge with us. I would also like to express my sincere gratitude to all participants who participate in this conference. Special acknowledgement should go to the Technical Program Committee Chairs, Members, and Reviewers for their thorough and timely reviewing of the papers. We would also like to thank our sponsors: IEEE Indonesia Section and Research and Society Service Institution at STMIK Akakom. Last but not least, recognition should also go to the Local Organizing Committee members who have put enormous effort and support for this conference. At last, we hope that you have an enjoyable and inspiring moment during our conference. Thank you for your participation in ISRITI 2020.

Yogyakarta, 10 December 2020

General Chair of the 3rd ISRITI 2020

\section{Dr. Bambang Purnomosidi D. P.}




\title{
PREFACE
}

A language and reasoning can be said as some of the characteristics of human abilities. On the other hand, the ability of human thinking can be modeled as computation. The development of cognitive science that combines scientific development with technology began to appear in the 1960s. In those years, human behavior did not adequately explain cognitive processes. Although, there has been much debate by behaviorist experts regarding the cognitive science approach. However, with a variety of approaches, there is something quite encouraging that computer models of cognition can be used as an alternative approach to these various models. Furthermore, computers can be used to test hypotheses where computation itself is the subject of the mind. So that there are various kinds of models developed in the field of cognitive science with different fields of science, including anthropology, artificial intelligence (AI), philosophy, linguistics, neuroscience, and psychology. Even though there are different scientific fields, it turns out that they can work together in explaining various kinds of cognitive science models. AI is a part of the field of computer science that can describe intelligent computer systems. This system can show characteristics related to intelligence in human behavior, such as reasoning, understanding language, learning, solving problems, and so on. This intelligent system has a long-term goal of equaling or surpassing human intelligence. The approach used in simulating this system uses mathematical approaches, discursive reasoning, language, and so on. New developments related to the paradigm in this field emerged in the mid-80s, bringing together developments in the fields of philosophy, AI, and cognitive science.

Human intelligence is illustrated as a result of a program running on the human brain. In connectionist's view, information processing on computer devices is a fundamental difference from the brain. In the contextsensitive cognition model, human intelligence depends on the physical properties of the neurons. So that artificial intelligence requires brain-like computer skills, better known as neurocomputers. The purpose of this terminology is to design hardware compatible with neuro-computing. In this case, the model that is later known massively is an artificial neural network in which this model is trained, not programmed. Much information is extracted deeper than a representation that is presented in various forms that can be understood by humans. In the past, artificial emotions were somewhat neglected in AI and cognitive science. However, currently, emotional intelligence is one of the things that is raised with relevant information indicators in solving a case or problem. Emotion has an important domain in motivating and directing behavior. So that discussions in cognitive science and AI become one of the raw materials in representing information, then use it in social interactions. This representation is a language capable of thinking about problem-solving and social processes. This explains the systematics or methods used are very important in understanding cognition and communication in the context of social interaction. This pattern has appeared in the childhood phase in the learning process until later understanding their identity and interacting with others in the form of communication. The basis for this transformation is then essential in solving many cases in the world of science and technology.

\section{Editor of 2020 3rd ISRITI}

\author{
Ferry Wahyu Wibowo \\ ORCID ID: 0000-0003-1913-436X
}




\section{THE COMMITTEE}

\section{STEERING COMMITTEE}

Chuan-Ming Liu

Totok Suprawoto

Widyastuti Andriyani

\section{ORGANIZING COMMITTEE}

General Chair

Bambang Purnomosidi Dwi Putranto

Deputi of General Chair

Maria Mediatrix

Secretary

Edy Prayitno

Treasury

Sumiyatun Sumiyatun

Publication Chair

Setyawan Widyarto

Chair of TPC

Domy Kristomo

\section{TECHNICAL COMMITTEE}

Muhammad Agung Nugroho

Luthfan Hadi Pramono

Siska Lidya Revianti

Ariesta Damayanti

Robby Cokro Buwono

Agung Budi Prasetyo

Muhammad Guntara
(National Taipei University of Technology, Taiwan)

(STMIK AKAKOM Yogyakarta, Indonesia)

(STMIK AKAKOM Yogyakarta, Indonesia)

(STMIK AKAKOM Yogyakarta, Indonesia)

(STMIK AKAKOM Yogyakarta, Indonesia)

(STMIK AKAKOM Yogyakarta, Indonesia)

(STMIK AKAKOM Yogyakarta, Indonesia)

(Universiti Selangor, Malaysia)

(STMIK AKAKOM Yogyakarta, Indonesia)

(STMIK AKAKOM Yogyakarta, Indonesia) (STMIK AKAKOM Yogyakarta, Indonesia) (STMIK AKAKOM Yogyakarta, Indonesia) (STMIK AKAKOM Yogyakarta, Indonesia) (STMIK AKAKOM Yogyakarta, Indonesia) (STMIK AKAKOM Yogyakarta, Indonesia) (STMIK AKAKOM Yogyakarta, Indonesia) 


\section{TECHNICAL PROGRAM COMMITTEE}

Prof. Biao Jiang

Prof. Dimitrios Kallergis

Prof. Domenico Ciuonzo

Prof. Iickho Song

Prof. Julian Webber

Prof. Muhammed Bashir Mu'azu

Prof. Mu-Song Chen

Prof. Philip Moore

Prof. Sanggyu Shin

Prof. Sayantam Sarkar

Prof. Srinivasulu Tadisetty

Prof. Thaweesak Yingthawornsuk

Prof. Yi-Jen Su

Dr. Abdul Samad Shibghatullah

Dr. Adi Wibowo

Dr. Aditi Sharma

Dr. Ahmad Ashari

Dr. Ahmad Fajar

Dr. Ahmed Mobashsher

Dr. Ali Rafiei

Dr. Amit Singh

Dr. Amrit Mukherjee

Dr. Anand Prasad

Dr. Anas AlSobeh

Dr. Andreas Dewald

Dr. Armin Lawi

Dr. Arti Arya

Dr. Aslina Baharum

Dr. Baba Alhaji

Dr. Bambang Purnomosidi Dwi Putranto

Dr. Chau Yuen

Dr. Danial Hooshyar

Dr. Dario Vieira

Dr. Dedi Rohendi

Dr. Dedy Wijaya

Dr. Dhananjay Singh

Dr. Dhomas Hatta Fudholi

Dr. Didi Rosiyadi

Dr. Enny Sela

Dr. Esa Prakasa

Dr. Hasan Ali Khattak

Dr. Hiroshi Kamabe

Dr. I Wayan Mustika

Dr. Ilker Ali Ozkan

Dr. Intan Ermahani A. Jalil

Dr. Iwan Setyawan

Dr. Javier Gozalvez

Dr. Kiran Sree Pokkuluri

Dr. Kok-Why $\mathrm{Ng}$

Dr. Leonardo Tomassetti Ferreira Neto

Dr. Maria Chiara Caschera

Dr. Michele Albano

Dr. Mithileysh Sathiyanarayanan

Dr. Mohd Hanafi Ahmad Hijazi

Dr. Muhammad Herman Jamaluddin

Dr. Muhammad Yusuf

Dr. N. Prabaharan
The City University of New York - United State of America

University of West Attica - Great Britain

University of Naples Federico II - Italia

Korea Advanced Institute of Science and Technology - Korea

Osaka University - Japan

Ahmadu Bello University, Zaria - Nigeria

Electrical Engineering, Da-Yeh University - Taiwan

Lanzhou University - China

Tokai University - Japan

Vijaya Vittala Institute of Technology - India

Kakatiya University College of Engineering and Technology -

India

King Mongkut's University of Technology Thonburi - Thailand

Shu-Te University - Taiwan

UCSI University - Malaysia

Diponegoro University - Indonesia

Quantum University, Roorkee, Uttarakhand - India

Gadjah Mada University - Indonesia

Bina Nusantara University - Indonesia

The University of Queensland - Australia

University of Technology Sydney - Australia

Guru Gobind Singh Indraprastha University - India

Jiangsu University - China

NEC Corporation - Japan

Yarmouk University - Jordan

ERNW Research GmbH - Germany

Hasanuddin University - Indonesia

PESIT-Bangalore South Campus - India

Universiti Malaysia Sabah - Malaysia

Nigerian Defence Academy - Nigeria

STMIK Akakom - Indonesia

Singapore University of Technology and Design - Singapore

Korea University - Korea

EFREI - France

Universitas Pendidikan Indonesia - Indonesia

Telkom University - Indonesia

Hankuk University of Foreign Studies - Korea

Universitas Islam Indonesia - Indonesia

Indonesian Institute of Sciences - Indonesia

Universitas Teknologi Yogyakarta - Indonesia

Indonesian Institute of Sciences - Indonesia

COMSATS University, Islamabad - Pakistan

Gifu University - Japan

Universitas Gadjah Mada - Indonesia

Selcuk University - Turkey

Universiti Teknikal Malaysia Melaka - Malaysia

Satya Wacana Christian University - Indonesia

Universidad Miguel Hernandez de Elche - Spain

Shri Vishnu Engineering College for Women - India

Multimedia University - Malaysia

University of Sao Paulo - Brazil

CNR - Italia

Aalborg University - Denmark

MIT Square - Great Britain

Universiti Malaysia Sabah - Malaysia

Universiti Teknikal Malaysia Melaka - Malaysia

University of Trunojoyo, Madura - Indonesia

SASTRA Deemed University - India 
Dr. Nico Surantha

Dr. Nitish Ojha

Dr. Noriko Etani

Dr. Othman Mohd

Dr. Oyas Wahyunggoro

Dr. Pavel Loskot

Dr. Prapto Nugroho

Dr. Praveen Khethavath

Dr. Rakan Antar

Dr. Ruzelita Ngadiran

Dr. Sa'adah Hassan

Dr. Seyed Ebrahim Esmaeili

Dr. Shajith Ali

Dr. Sri Zuliana

Dr. Sritrusta Sukaridhoto

Dr. Sudi Mungkasi

Dr. Suhail Shahab

Dr. Sukrisno Mardiyanto

Dr. Suryadiputra Liawatimena

Dr. Tai-Chen Chen

Dr. Tapodhir Acharjee

Dr. Tri Priyambodo

Dr. Vassilis Kodogiannis

Dr. Weiwen Zhang

Dr. Wichian Chutimaskul

Dr. Yuansong Qiao

Dr. Zoohan Gani

Mr. Alireza Ghasempour

Mr. Andi Wahju Rahardjo Emanuel

Mr. Arihant Jain

Mr. Azizi Abdullah

Mr. Byeong-jun Han

Mr. De Rosal Ignatius Moses Setiadi

Mr. Domy Kristomo

Mr. Edhy Sutanta

Mr. Edi Faizal

Mr. Eko Aribowo

Mr. Gunawan Gunawan

Mr. Ibrahim Ahmad

Mr. Leonel Hernandez

Mr. Mahdin Mahboob

Mr. Mohd Khairul Ikhwan Ahmad

Mr. Ramkumar Jaganathan

Mr. Ridi Ferdiana

Mr. Rifqy Hakimi

Mr. Rikie Kartadie

Mr. Roberto Carlos Herrera Lara

Mr. Seng Hansun

Mr. Shah Nazir

Mr. Syed Ahmed

Mr. Vaibhav Saundarmal

Mr. Vladislav Skorpil

Mr. Wijang Widhiarso

Mr. Win Maung

Mrs. Amel Serrat

Mrs. Anindita Septiarini

Mrs. Ariesta Damayanti

Mrs. Haslizatul Mohamed Hanum

Mrs. Kartika Kirana

Mrs. Lucia Nugraheni Harnaningrum
Bina Nusantara University - Indonesia

Sharda University, Greater Noida, UP - India

All Nippon Airways Co., Ltd. - Japan

Universiti Teknikal Malaysia Melaka - Malaysia

UGM - Indonesia

Swansea University - Great Britain

Universitas Gadjah Mada - Indonesia

LaGuardia Community College - United State of America

Northern Technical University - Iraq

Universiti Malaysia Perlis - Malaysia

Universiti Putra Malaysia - Malaysia

American University of Kuwait - Kuwait

SSN College of Engineering, Chennai - India

UIN Sunan Kalijaga - Indonesia

Politeknik Elektronika Negeri Surabaya - Indonesia

Sanata Dharma University - Indonesia

Northern Technical University - Iraq

Institut Teknologi Bandung - Indonesia

Bina Nusantara University - Indonesia

MAXEDA Technology - Taiwan

Assam University, Silchar - India

Universitas Gadjah Mada - Indonesia

University of Westminster - Great Britain

Guangdong University of Technology - China

King Mongkut's University of Technology Thonburi - Thailand

Athlone Institute of Technology - Ireland

Victoria University - Australia

ICT Faculty - United State of America

Universitas Atma Jaya Yogyakarta - Indonesia

Jaipur Engineering College \& Research Centre - India

Universiti Kebangsaan Malaysia - Malaysia

Soongsil University - Korea

Dian Nuswantoro University - Indonesia

STMIK AKAKOM Yogyakarta - Indonesia

Institut Sains \& Teknologi AKPRIND Yogyakarta - Indonesia

STMIK AKAKOM Yogyakarta - Indonesia

Ahmad Dahlan University - Indonesia

Politeknik Negeri Medan - Indonesia

Universiti Teknikal Malaysia Melaka - Malaysia

ITSA University - Colombia

Stony Brook University - United State of America

Universiti Tun Hussein Onn Malaysia - Malaysia

VLB Janakiammal College of Arts and Science - India

Universitas Gadjah Mada - Indonesia

ITB - Indonesia

STMIK Akakom Jogjakarta - Indonesia

National Polytechnic School - Ecuador

Universitas Multimedia Nusantara - Indonesia

University of Peshawar - Pakistan

NED University of Engineering and Technology - Pakistan

Marathwada Institute of Technology, Aurangabad - India

Brno University of Technology - Czech Republic

STMIK Global Informatika MDP Palembang - Indonesia

Victorian Institute of Technology - Australia

USTO MB - Algeria

Univeristas Mulawarman - Indonesia

STMIK Akakom Yogyakarta - Indonesia

Universiti Teknologi MARA - Malaysia

Universitas Negeri Malang - Indonesia

STMIK AKAKOM Yogyakarta - Indonesia 
Mrs. Prita Dewi Mariyam Mrs. Sri Redjeki

Ms. Ivanna Timotius Ms. Maria Mediatrix
Universitas Indonesia - Indonesia

STMIK AKAKOM Yogyakarta - Indonesia

Satya Wacana Christian University - Indonesia

STMIK AKAKOM - Indonesia 


\title{
REVIEWERS
}

\author{
Dr. Intan Ermahani A. Jalil \\ Mr. Azizi Abdullah \\ Dr. Tapodhir Acharjee \\ Mr. Ibrahim Ahmad \\ Mr. Mohd Khairul Ikhwan Bin Ahmad \\ Mr. Syed Umaid Ahmed NED \\ Dr. Michele Albano \\ Dr. Baba Alhaji \\ Dr. Shajith Ali \\ Dr. Anas Mohammad Ramadan AlSobeh \\ Dr. Rakan Khalil Antar \\ Mr. Eko Aribowo \\ Dr. Arti Arya \\ Dr. Ahmad Ashari \\ Dr. Aslina Baharum \\ Dr. Maria Chiara Caschera \\ Prof. Mu-Song Chen \\ Dr. Tai-Chen Chen \\ Dr. Wichian Chutimaskul \\ Prof. Domenico Ciuonzo \\ Mr. Akhmad Dahlan \\ Mrs. Ariesta Damayanti \\ Dr. Andreas Dewald \\ Mr. Andi Wahju Rahardjo Emanuel \\ Dr. Seyed Ebrahim Esmaeili \\ Dr. Noriko Etani \\ Mr. Edi Faizal \\ Dr. Ahmad Nurul Fajar \\ Mr. Ridi Ferdiana \\ Dr. Dhomas Hatta Fudholi \\ Mrs. Zoohan Gani \\ Mr. Alireza Ghasempour \\ Dr. Javier Gozalvez \\ Mr. Gunawan Gunawan \\ Mr. Ibnu Hadi Purwanto \\ Mr. Rifqy Hakimi \\ Mr. Byeong-jun Han \\ Mr. Seng Hansun \\ Dr. Sa'adah Hassan \\ Mr. Leonel Hernandez \\ Mr. Roberto Carlos Herrera Lara \\ Dr. Mohd Hanafi Ahmad Hijazi \\ Dr. Danial Hooshyar \\ Mr. Ramkumar Jaganathan \\ Mr. Arihant Kumar Jain \\ Dr. Muhammad Herman Jamaluddin \\ Prof. Biao Jiang \\ Prof. Dimitrios Kallergis \\ Dr. Hiroshi Kamabe \\ Dr. Hasan Ali Khattak \\ Dr. Praveen Khethavath \\ Mrs. Kartika Candra Kirana \\ Dr. Vassilis Kodogiannis \\ Mr. Domy Kristomo \\ Dr. Armin Lawi \\ Dr. Suryadiputra Liawatimena \\ Dr. Pavel Loskot \\ Mr. Mahdin Mahboob \\ Universiti Teknikal Malaysia Melaka, Malaysia \\ Universiti Kebangsaan Malaysia, Malaysia \\ Assam University, Silchar, India \\ Universiti Teknikal Malaysia Melaka, Malaysia \\ Universiti Tun Hussein Onn Malaysia, Malaysia \\ University of Engineering and Technology, Pakistan \\ Aalborg University, Denmark \\ Nigerian Defence Academy, Niger \\ SSN College of Engineering, Chennai, India \\ Yarmouk University, Jordan \\ Northern Technical University, Iraq \\ Ahmad Dahlan University, Indonesia \\ PESIT-Bangalore South Campus, India \\ Gadjah Mada University, Indonesia \\ Universiti Malaysia Sabah, Malaysia \\ CNR, Italy \\ Electrical Engineering, Da-Yeh University, Taiwan \\ MAXEDA Technology, Taiwan \\ King Mongkut's University of Technology Thonburi, Thailand \\ University of Naples Federico II, IT, Italy \\ Universitas Amikom Yogyakarta, Indonesia \\ STMIK Akakom Yogyakarta, Indonesia \\ ERNW Research GmbH, Germany \\ Universitas Atma Jaya Yogyakarta, Indonesia \\ American University of Kuwait, Kuwait \\ All Nippon Airways Co., Ltd., Japan \\ STMIK AKAKOM Yogyakarta, Indonesia \\ Bina Nusantara University, Indonesia \\ Universitas Gadjah Mada, Indonesia \\ Universitas Islam Indonesia, Indonesia \\ Victoria University, Australia \\ ICT Faculty, USA \\ Universidad Miguel Hernandez de Elche, Spain \\ Politeknik Negeri Medan, Indonesia \\ Universitas AMIKOM Yogyakarta, Indonesia \\ ITB, Indonesia \\ Soongsil University, Korea (South) \\ Universitas Multimedia Nusantara, Indonesia \\ Universiti Putra Malaysia, Malaysia \\ ITSA University, Colombia \\ National Polytechnic School, Ecuador \\ Universiti Malaysia Sabah, Malaysia \\ Korea University, Korea (South) \\ VLB Janakiammal College of Arts and Science, India \\ Jaipur Engineering College \& Research Centre, India \\ Universiti Teknikal Malaysia Melaka, Malaysia \\ The City University of New York, USA \\ University of West Attica, Greece \\ Gifu University, Japan \\ COMSATS University, Islamabad, Pakistan \\ LaGuardia Community College, USA \\ Universitas Negeri Malang, Indonesia \\ University of Westminster, United Kingdom (Great Britain) \\ STMIK AKAKOM Yogyakarta, Indonesia \\ Hasanuddin University, Indonesia \\ Bina Nusantara University, Indonesia \\ Swansea University, United Kingdom (Great Britain) \\ Stony Brook University, USA
}


Dr. Sukrisno Mardiyanto

Mrs. Prita Dewi Mariyam

Mr. Win Maung

Ms. Maria Mediatrix

Dr. Ahmed Toaha Mobashsher

Mrs. Haslizatul Mohamed Hanum

Dr. Othman Mohd

Prof. Philip T Moore

Prof. Muhammed Bashir Mu'azu

Dr. Amrit Mukherjee

Dr. Sudi Mungkasi

Dr. I Wayan Mustika

Mr. Shah Nazir

Dr. Kok-Why Ng

Dr. Ruzelita Ngadiran

Mr. Muhammad Agung Nugroho

Dr. Prapto Nugroho

Dr. Nitish Ojha

Dr. Ilker Ali Ozkan

Dr. Kiran Sree Pokkuluri

Dr. N. Prabaharan

Dr. Esa Prakasa

Dr. Anand R. Prasad

Mr. Edy Prayitno

Dr. Tri K Priyambodo

Dr. Bambang Purnomosidi Dwi Putranto

Dr. Yuansong Qiao

Dr. Ali Rafiei

Mrs. Sri Redjeki

Dr. Dedi Rohendi

Dr. Didi Rosiyadi

Dr. Rosaria Rucco

Prof. Sayantam Sarkar

Dr. Mithileysh Sathiyanarayanan

Mr. Vaibhav Dudhaji Saundarmal

Dr. Enny Sela

Mrs. Anindita Septiarini

Mrs. Amel Serrat

Mr. De Rosal Ignatius Moses Setiadi

Dr. Iwan Setyawan

Dr. Suhail Najm Shahab

Dr. Aditi Sharma

Dr. Abdul Samad Shibghatullah

Prof. Sanggyu Shin

Dr. Amit Prakash Singh

Dr. Dhananjay Singh

Mr. Wangjam Niranjan Singh

Mr. Vladislav Skorpil

Prof. Iickho Song

Prof. Yi-Jen Su

Dr. Sritrusta Sukaridhoto

Mr. Totok Suprawoto

Dr. Nico Surantha

Mr. Edhy Sutanta

Prof. Srinivasulu Tadisetty

Ms. Ivanna Timotius

Dr. Leonardo Henrique Tomassetti Ferreira Neto

Dr. Oyas Wahyunggoro

Prof. Julian L Webber

Dr. Adi Wibowo
Institut Teknologi Bandung, Indonesia

Universitas Indonesia, Indonesia

Victorian Institute of Technology, Australia

STMIK AKAKOM, Indonesia

The University of Queensland, Australia

Universiti Teknologi MARA, Malaysia

Universiti Teknikal Malaysia Melaka, Malaysia

Lanzhou University, China

Ahmadu Bello University, Zaria, Nigeria

Jiangsu University, China

Sanata Dharma University, Indonesia

Universitas Gadjah Mada, Indonesia

University of Peshawar, Pakistan

Multimedia University, Malaysia

Universiti Malaysia Perlis, Malaysia

STMIK AKAKOM Yogyakarta, Indonesia

Universitas Gadjah Mada, Indonesia

Sharda University, Greater Noida, UP, India

Selcuk University, Turkey

Shri Vishnu Engineering College for Women, India

SASTRA Deemed University, India

Indonesian Institute of Sciences, Indonesia

NEC Corporation, Japan

STMIK AKAKOM Yogyakarta, Indonesia

Universitas Gadjah Mada, Indonesia

STMIK Akakom, Indonesia

Athlone Institute of Technology, Ireland

University of Technology Sydney, Australia

STMIK AKAKOM Yogyakarta, Indonesia

Universitas Pendidikan Indonesia, Indonesia

Indonesian Institute of Sciences, Indonesia

University of Naples Parthenope, Italy

Vijaya Vittala Institute of Technology, India

MIT Square, United Kingdom (Great Britain)

Marathwada Institute of Technology, Aurangabad, India

Universitas Teknologi Yogyakarta, Indonesia

Univeristas Mulawarman, Indonesia

USTO MB, Algeria

Dian Nuswantoro University, Indonesia

Satya Wacana Christian University, Indonesia

Northern Technical University, Iraq

Quantum University, Roorkee, Uttarakhand, India

UCSI University, Malaysia

Tokai University, Japan

Guru Gobind Singh Indraprastha University, India

Hankuk University of Foreign Studies, Korea (South)

Assam University, India

Brno University of Technology, Czech Republic

Korea Advanced Institute of Science and Technology, Korea (South)

Shu-Te University, Taiwan

Politeknik Elektronika Negeri Surabaya, Indonesia

STMIK AKAKOM Yogyakarta, Indonesia

Bina Nusantara University, Indonesia

Institut Sains \& Teknologi AKPRIND Yogyakarta, Indonesia

Kakatiya University College of Engineering and Technology, India

Satya Wacana Christian University, Indonesia

UGM, Indonesia

Osaka University, Japan

Diponegoro University, Indonesia 
Prof. Thaweesak Yingthawornsuk

Dr. Chau Yuen

Dr. Muhammad Yusuf

Dr. Weiwen Zhang

Dr. Sri Utami Zuliana

Mr. Ferry Wahyu Wibowo

Mr. Wijang Widhiarso

Dr. Dedy Rahman Wijaya
King Mongkut's University of Technology Thonburi, Thailand Singapore University of Technology and Design, Singapore University of Trunojoyo, Madura, Indonesia

Guangdong University of Technology, China

UIN Sunan Kalijaga, Indonesia

Universitas Amikom Yogyakarta, Indonesia

STMIK Global Informatika MDP Palembang, Indonesia

Telkom University, Indonesia 


\section{AUTHOR INDEX}

\begin{tabular}{|c|c|c|c|}
\hline Author & Session & Start page & Title \\
\hline \multicolumn{4}{|c|}{ A B C D E F G H I J K L M N O P Q R T U W X Y Z } \\
\hline Abadi, Imam & $3 \mathrm{E} .3$ & 716 & $\begin{array}{l}\text { Energy Management Efficiency and Stability Using } \\
\text { Passive Filter in Standalone Photovoltaic Sudden } \\
\text { Cloud Condition }\end{array}$ \\
\hline Abdillah, Rahmad & 3A.1 & 621 & $\begin{array}{l}\text { Facial Expression Recognition and Face } \\
\text { Recognition Using a Convolutional Neural Network }\end{array}$ \\
\hline Abdul-Jabbar, Jassim & $3 B .4$ & 655 & $\begin{array}{l}\text { A Robust Iris Segmentation Algorithm Based on } \\
\text { Pupil Region for Visible Wavelength Environments }\end{array}$ \\
\hline Adi, Sumarni & $1 C .2$ & 94 & $\begin{array}{l}\text { The Best Parameter Tuning on RNN Layers for } \\
\text { Indonesian Text Classification }\end{array}$ \\
\hline Aditya, Christian Sri Kusuma & $1 \mathrm{D} .5$ & 152 & $\begin{array}{l}\text { Comparative Analysis of DDoS Detection } \\
\text { Techniques Based on Machine Learning in } \\
\text { OpenFlow Network }\end{array}$ \\
\hline Aditya, Trias & $2 \mathrm{G} .5$ & 604 & $\begin{array}{l}\text { Comparison of the Latest DTM with DEM Pleiades } \\
\text { in Monitoring the Dynamic Peatland }\end{array}$ \\
\hline Adrian, Ronald & $1 \mathrm{E} .5$ & 198 & $\begin{array}{l}\text { Roadside Unit Power Saving using Vehicle } \\
\text { Detection System in Vehicular Ad-hoc Network }\end{array}$ \\
\hline Afdhal, Afdhal & $2 \mathrm{E} .3$ & 509 & $\begin{array}{l}\text { Convolutional Network and Moving Object } \\
\text { Analysis for Vehicle Detection in Highway } \\
\text { Surveillance Videos }\end{array}$ \\
\hline Affandi, Achmad & $1 G .1$ & 267 & $\begin{array}{l}\text { A Combination of Defected Ground Structure and } \\
\text { Line Resonator for Mutual Coupling Reduction }\end{array}$ \\
\hline Agustina, Dina & $1 B .2$ & 48 & $\begin{array}{l}\text { Prediction of forest fire occurrence in peatlands } \\
\text { using machine learning approaches }\end{array}$ \\
\hline Akbar, Renal & $1 \mathrm{D.6}$ & 158 & $\begin{array}{l}\text { Performance Analysis FSR and DSR Routing } \\
\text { Protocol in VANET with V2V and V2I Models }\end{array}$ \\
\hline Akhsanta, Muhammad & 2E.6 & 525 & $\begin{array}{l}\text { Text-Independent Speaker Identification Using } \\
\text { PCA-SVM Model }\end{array}$ \\
\hline Al Aufa, Badra & $2 F .6$ & 562 & $\begin{array}{l}\text { Measuring Instagram Activity and Engagement } \\
\text { Rate of Hospital: A Comparison Before and During } \\
\text { COVID-19 Pandemic }\end{array}$ \\
\hline Al Maki, Wikky & $1 B .8$ & 73 & $\begin{array}{l}\text { Hybrid Method for Flower Classification in High } \\
\text { Intra-class Variation }\end{array}$ \\
\hline Alam, Sahirul & $1 \mathrm{E} .5$ & 198 & $\begin{array}{l}\text { Roadside Unit Power Saving using Vehicle } \\
\text { Detection System in Vehicular Ad-hoc Network }\end{array}$ \\
\hline
\end{tabular}




\begin{tabular}{|c|c|c|c|}
\hline Alamsyah, Rangga & $3 B .2$ & 646 & $\begin{array}{l}\text { Speech Gender Classification Using Bidirectional } \\
\text { Long Short Term Memory }\end{array}$ \\
\hline Alfi, Farah & 1F.2 & 227 & $\begin{array}{l}\text { Quality Assessment of Digital Terrestrial Television } \\
\text { Broadcast in Surabaya }\end{array}$ \\
\hline Ali, Tarig Ahmed El Khider & $1 B .7$ & 68 & $\begin{array}{l}\text { Risk Prediction of Major Depressive Disorder using } \\
\text { Artificial Neural Network }\end{array}$ \\
\hline Alief, Fahdiaz & $1 F .3$ & 233 & $\begin{array}{l}\text { Android Forensic Tools Analysis for Unsend Chat } \\
\text { on Social Media }\end{array}$ \\
\hline Amalia, Yasmin & $2 \mathrm{D} .2$ & 457 & $\begin{array}{l}\text { Benchmarking Explicit Rating Prediction } \\
\text { Algorithms for Cosmetic Products }\end{array}$ \\
\hline Amanaf, Muntaqo & $1 G .3$ & 278 & $\begin{array}{l}5 G \text { New Radio (NR) Network Planning at } \\
\text { Frequency } 2,6 \mathrm{GHz} \text { in The Gold Triangle Area of } \\
\text { Jakarta }\end{array}$ \\
\hline Ambarwari, Agus & 2B.7 & 389 & $\begin{array}{l}\text { Design and prototype development of internet of } \\
\text { things for greenhouse monitoring system }\end{array}$ \\
\hline \multirow[t]{2}{*}{ Andriyani, Widyastuti } & $2 B .6$ & 383 & $\begin{array}{l}\text { A Comparative Study of Java and Kotlin for } \\
\text { Android Mobile Application Development }\end{array}$ \\
\hline & $1 \mathrm{~B} .2$ & 48 & $\begin{array}{l}\text { Prediction of forest fire occurrence in peatlands } \\
\text { using machine learning approaches }\end{array}$ \\
\hline Anggraeni, Martianda & 1F.2 & 227 & $\begin{array}{l}\text { Quality Assessment of Digital Terrestrial Television } \\
\text { Broadcast in Surabaya }\end{array}$ \\
\hline Annisa, Fadhilah Qalbi & $1 B .8$ & 79 & $\begin{array}{l}\text { Personality Dimensions Classification with EEG } \\
\text { Analysis using Support Vector Machine }\end{array}$ \\
\hline Antonius, Suyanto & $2 \mathrm{E} .7$ & 529 & $\begin{array}{l}\text { Center of Gravity Method for Finding Center of } \\
\text { Laser Beam Projection on Landslide Measurement }\end{array}$ \\
\hline Anugraha, Tides & $1 D .3$ & 140 & $\begin{array}{l}\text { Experimental Security Analysis for Fake eNodeB } \\
\text { Attack on LTE Network }\end{array}$ \\
\hline Anwar, Muchamad Taufiq & $1 C .1$ & 83 & $\begin{array}{l}\text { Performance Comparison of Data Mining } \\
\text { Techniques for Rain Prediction Models in Indonesia }\end{array}$ \\
\hline Archi, Muhammad & 1E.2 & 182 & $\begin{array}{l}\text { Initial Access in } 5 G \text { mmWave Communication } \\
\text { using Hybrid Genetic Algorithm and Particle } \\
\text { Swarm Optimization }\end{array}$ \\
\hline Ardiansyah, Agus & $2 B .5$ & 377 & $\begin{array}{l}\text { Prototype Design of IoT (Internet of Things)-based } \\
\text { Load Monitoring System }\end{array}$ \\
\hline Arfian, Nur & 2B.1 & 354 & $\begin{array}{l}\text { The User Experience effect of Applying Floating } \\
\text { Action Button (FAB) into Augmented Reality } \\
\text { Anatomy Cranium Media Learning Prototype }\end{array}$ \\
\hline Ariananda, Dyonisius & $1 F .5$ & 245 & $\begin{array}{l}\text { Single Snapshot-Spatial Compressive Beamforming } \\
\text { for Azimuth Estimation and Backscatter } \\
\text { Reconstruction }\end{array}$ \\
\hline
\end{tabular}




\begin{tabular}{|c|c|c|c|}
\hline Aripriharta, A. & $2 B .4$ & 371 & $\begin{array}{l}\text { Development of The Personnel Monitoring System } \\
\text { Using Mobile Application and Real-Time Database } \\
\text { During the COVD19 Pandemic }\end{array}$ \\
\hline Arisanty, Deasy & $1 B .2$ & 48 & $\begin{array}{l}\text { Prediction of forest fire occurrence in peatlands } \\
\text { using machine learning approaches }\end{array}$ \\
\hline Arisya, Khairunnisa & $1 \mathrm{D} .8$ & 170 & $\begin{array}{l}\text { Measurement of Information Security Awareness } \\
\text { Level: A Case Study of Online Transportation } \\
\text { Users }\end{array}$ \\
\hline \multirow[t]{2}{*}{ Armin, Farid } & $1 G .4$ & 284 & $\begin{array}{l}\text { Modification of } 2.2 \mathrm{GHz} \text { S-Band Rectangular Patch } \\
\text { Microstrip Antenna using Truncated Corner Method } \\
\text { for Satellite Applications }\end{array}$ \\
\hline & $1 G .5$ & 289 & $\begin{array}{l}\text { Design of Optimal Satellite Constellation for } \\
\text { Indonesian Regional Navigation System based on } \\
\text { GEO and GSO Satellites }\end{array}$ \\
\hline Arwoko, Heru & 3D.1 & 682 & $\begin{array}{l}\text { Fruits Classification from Image using MPEG-7 } \\
\text { Visual Descriptors and Extreme Learning Machine }\end{array}$ \\
\hline Asfihani, Tahiyatul & $1 G .8$ & 306 & $\begin{array}{l}\text { Ship Heading Control Using Nonlinear Model } \\
\text { Predictive Control }\end{array}$ \\
\hline Asriningtias, Salnan & $1 \mathrm{~A} .2$ & 7 & $\begin{array}{l}\text { Blackbox Testing Model Boundary Value of } \\
\text { Mapping Taxonomy Applications and Data } \\
\text { Analysis of Art and Artworks }\end{array}$ \\
\hline Astuti, Eha Renwi & 3 C. 2 & 661 & $\begin{array}{l}\text { The Use of Pre and Post Processing to Enhance } \\
\text { Mandible Segmentation using Active Contours on } \\
\text { Dental Panoramic Radiography Images }\end{array}$ \\
\hline Astuti, Yenni & 3B.1 & 642 & $\begin{array}{l}\text { Comparison of Feature Extraction for Speaker } \\
\text { Identification System }\end{array}$ \\
\hline Asyrofi, Rakha & $2 \mathrm{~A} .5$ & 332 & $\begin{array}{l}\text { Extraction Dependency Based on Evolutionary } \\
\text { Requirement Using Natural Language Processing }\end{array}$ \\
\hline \multicolumn{4}{|c|}{ B A B C D E F G H I K L M N O P Q R S T U X Y Z } \\
\hline Basari, Basari & $2 B .3$ & 365 & $\begin{array}{l}\text { Proximity-based COVD-19 Contact Tracing } \\
\text { System Devices for Locally Problems Solution }\end{array}$ \\
\hline \multirow[t]{2}{*}{ Bejo, Agus } & 3B.1 & 642 & $\begin{array}{l}\text { Comparison of Feature Extraction for Speaker } \\
\text { Identification System }\end{array}$ \\
\hline & $1 B .3$ & 52 & $\begin{array}{l}\text { Speaker Recognition Using Mel Frequency Cepstral } \\
\text { Coefficient and Self-Organising Fuzzy Logic }\end{array}$ \\
\hline Belangour, Abdessamad & 3A.4 & 638 & A Kubernetes Algorithm for scaling Virtual Objects \\
\hline Borman, Rohmat & $2 \mathrm{E} .5$ & 520 & $\begin{array}{l}\text { Indonesian Traffic Sign Recognition For Advanced } \\
\text { Driver Assistent (ADAS) Using YOLOv4 }\end{array}$ \\
\hline
\end{tabular}




\begin{tabular}{|l|l|l|l|}
\hline Budi Setiawan, Fajar & 1E.8 & $\begin{array}{l}215 \\
\text { Performance Enhancement in Macro-Femto } \\
\text { Network Using a Modified Discrete Moth-flame } \\
\text { Optimization Algorithm }\end{array}$ \\
\hline Budiman, Edy & $2 \mathrm{D} .7$ & 482 & $\begin{array}{l}\text { Dayak Onion (Eleutherine palmifolia (L) Merr) as } \\
\text { An Alternative Treatment in Early Detection of } \\
\text { Dental Caries using Certainty Factor }\end{array}$ \\
\hline Bustamam, Alhadi & $\mathbf{1 A . 6}$ & 26 & $\begin{array}{l}\text { The Multimodal Transfer Learning for Diagnosing } \\
\text { COVW-19 Pneumonia from Chest CT-Scan and X- } \\
\text { Ray Images }\end{array}$ \\
\hline
\end{tabular}

\section{A B C D E F G H J K L N N P Q R T U W X Y Z}

\begin{tabular}{|l|l|l|l|}
\hline Cahyani, Denis & 1B.4 & $\begin{array}{l}56 \\
\text { Indonesian Parsing using Probabilistic Context- } \\
\text { Free Grammar (PCFG) and Viterbi-Cocke Young } \\
\text { Kasami (Viterbi-CYK) }\end{array}$ \\
\hline Chotimah, Khusnul & $\mathbf{1 G . 8}$ & $306 \begin{array}{l}\text { Ship Heading Control Using Nonlinear Model } \\
\text { Predictive Control }\end{array}$ \\
\hline
\end{tabular}

\section{A B C D E F G H I K L M N O P Q R T U W X Y Z}

\begin{tabular}{|c|c|c|c|}
\hline Daelami, Ahmad & $2 F .5$ & 551 & $\begin{array}{l}\text { Development of Temperature and Humidity } \\
\text { Control System in Internet-of-Things based Oyster } \\
\text { Mushroom Cultivation }\end{array}$ \\
\hline Darari, Fariz & $2 \mathrm{D} .2$ & 457 & $\begin{array}{l}\text { Benchmarking Explicit Rating Prediction } \\
\text { Algorithms for Cosmetic Products }\end{array}$ \\
\hline Delfianti, Rezi & 3E.3 & 716 & $\begin{array}{l}\text { Energy Management Efficiency and Stability Using } \\
\text { Passive Filter in Standalone Photovoltaic Sudden } \\
\text { Cloud Condition }\end{array}$ \\
\hline Dewantara, Mahardira & 2C.1 & 400 & $\begin{array}{l}\text { Minimization of Power Losses through Optimal } \\
\text { Placement and Sizing from Solar Power and Battery } \\
\text { Energy Storage System in Distribution System }\end{array}$ \\
\hline Dirgantoro, Burhanuddin & 2E.4 & 514 & $\begin{array}{l}\text { Speaker Recognition For Digital Forensic Audio } \\
\text { Analysis Using Support Vector Machine }\end{array}$ \\
\hline Djawas, Faizah & $2 F .6$ & 562 & $\begin{array}{l}\text { Measuring Instagram Activity and Engagement } \\
\text { Rate of Hospital: A Comparison Before and During } \\
\text { COVW-19 Pandemic }\end{array}$ \\
\hline Dwijayanti, Suci & 3A.1 & 621 & $\begin{array}{l}\text { Facial Expression Recognition and Face } \\
\text { Recognition Using a Convolutional Neural Network }\end{array}$ \\
\hline Dwiputra, Richard & 1E.6 & 203 & $\begin{array}{l}\text { Network Attack Detection System Using Filter- } \\
\text { based Feature Selection and SVM }\end{array}$ \\
\hline
\end{tabular}

\section{E A B C D E F G H I K L M N O P R S T U X Y Z}

Eka Sari, Wahyuni

$1 B .1$

42 Papaya Disease Detection Using Fuzzy Naïve Bayes Classifier 


\begin{tabular}{|c|c|c|c|}
\hline Ekaniza, Raki & $1 \mathrm{~A} .5$ & 21 & $\begin{array}{l}\text { PSO-Learned Artificial Neural Networks for } \\
\text { Activity Recognition }\end{array}$ \\
\hline Eko Sulistyo, Meiyanto & 2C.6 & 428 & $\begin{array}{l}\text { Design and Development of Bit Error Measurement } \\
\text { using FPGA for Visible Light Communication }\end{array}$ \\
\hline E1 Khalyly, Badr & 3A.4 & 638 & A Kubernetes Algorithm for scaling Virtual Objects \\
\hline Elsa, Corry & 2G.1 & 577 & $\begin{array}{l}\text { Case Study: AppDynamics Application as Business } \\
\text { Intelligence to Support Digital Business Operations } \\
\text { at PT PGD }\end{array}$ \\
\hline Emanuel, Andi Wahju Rahardjo & $1 C .3$ & 100 & $\begin{array}{l}\text { Influence Distribution Training Data on } \\
\text { Performance Supervised Machine Learning } \\
\text { Algorithms }\end{array}$ \\
\hline Engel, Ventje & $1 \mathrm{E} .6$ & 203 & $\begin{array}{l}\text { Network Attack Detection System Using Filter- } \\
\text { based Feature Selection and SVM }\end{array}$ \\
\hline \multicolumn{4}{|c|}{ F A B C D E F G H I K L M N O P Q R T U W X Y Z } \\
\hline Fachrie, Muhammad & 2G.1 & 583 & $\begin{array}{l}\text { Guided Genetic Algorithm to Solve University } \\
\text { Course Timetabling with Dynamic Time Slot }\end{array}$ \\
\hline Fadhilah, Amanda & $1 \mathrm{D.8}$ & 170 & $\begin{array}{l}\text { Measurement of Information Security Awareness } \\
\text { Level: A Case Study of Online Transportation } \\
\text { Users }\end{array}$ \\
\hline Fahmi, Fahmi & 2B.4 & 371 & $\begin{array}{l}\text { Development of The Personnel Monitoring System } \\
\text { Using Mobile Application and Real-Time Database } \\
\text { During the COVD19 Pandemic }\end{array}$ \\
\hline Fahrudin, Tresna & 2A.7 & 344 & $\begin{array}{l}\text { Indonesian Stock Price Prediction including } \\
\text { Covid19 Era Using Decision Tree Regression }\end{array}$ \\
\hline Fanani, M. & $1 \mathrm{C.7}$ & 117 & $\begin{array}{l}\text { Implementation of Maximum Power Point } \\
\text { Tracking on PV System using Artificial Bee Colony } \\
\text { Algorithm }\end{array}$ \\
\hline Faraby, Muhira & 2C.4 & 418 & $\begin{array}{l}\text { The Single Tuned Filter Planning to Mitigate } \\
\text { Harmonic Pollution in Radial Distribution Network } \\
\text { Using Particle Swarm Optimization }\end{array}$ \\
\hline Fardan, Fardan & $1 D .3$ & 140 & $\begin{array}{l}\text { Experimental Security Analysis for Fake eNodeB } \\
\text { Attack on LTE Network }\end{array}$ \\
\hline Farrell, Mochammad & 2E.3 & 505 & $\begin{array}{l}\text { Combined Firefly Algorithm-Random Forest to } \\
\text { Classify Autistic Spectrum Disorders }\end{array}$ \\
\hline Fatichah, Chastine & $3 C .2$ & 661 & $\begin{array}{l}\text { The Use of Pre and Post Processing to Enhance } \\
\text { Mandible Segmentation using Active Contours on } \\
\text { Dental Panoramic Radiography Images }\end{array}$ \\
\hline Ferdiansyah, Indra & 1C.7 & 117 & $\begin{array}{l}\text { Implementation of Maximum Power Point } \\
\text { Tracking on PV System using Artificial Bee Colony } \\
\text { Algorithm }\end{array}$ \\
\hline
\end{tabular}




\begin{tabular}{|c|c|c|c|}
\hline & 2 C. 3 & 412 & $\begin{array}{l}\text { Design and Implementation of SVPWM Inverter to } \\
\text { Reduce Total Harmonic Distortion (THD) on Three } \\
\text { Phase Induction Motor Speed Regulation Using } \\
\text { Constant V/F }\end{array}$ \\
\hline & $2 \mathrm{C} .2$ & 406 & $\begin{array}{l}\text { Three Phase Induction Motor Dynamic Speed } \\
\text { Regulation Using IP Controller }\end{array}$ \\
\hline Firdaus, Diash & $1 \mathrm{D} .7$ & 164 & $\begin{array}{l}\text { DDoS Attack Detection in Software Defined } \\
\text { Network using Ensemble K-means++ and Random } \\
\text { Forest }\end{array}$ \\
\hline Firdaus, Diaz & $2 \mathrm{D} .6$ & 476 & $\begin{array}{l}\text { Topic-Based Tweet Clustering for Public Figures } \\
\text { Using Ant Clustering }\end{array}$ \\
\hline Fitria, Irma & $1 G .8$ & 306 & $\begin{array}{l}\text { Ship Heading Control Using Nonlinear Model } \\
\text { Predictive Control }\end{array}$ \\
\hline Fitriati, Andi & $2 \mathrm{C} .4$ & 418 & $\begin{array}{l}\text { The Single Tuned Filter Planning to Mitigate } \\
\text { Harmonic Pollution in Radial Distribution Network } \\
\text { Using Particle Swarm Optimization }\end{array}$ \\
\hline Frannita, Eka & 2E.2 & 499 & $\begin{array}{l}\text { Supervised Deep Learning for Thyroid Nodules } \\
\text { Classification Based on Margin Characteristic }\end{array}$ \\
\hline \multicolumn{4}{|l|}{ G } \\
\hline Ginting, Ishak & $1 \mathrm{D} .3$ & 140 & $\begin{array}{l}\text { Experimental Security Analysis for Fake eNodeB } \\
\text { Attack on LTE Network }\end{array}$ \\
\hline Gitakarma, Made Santo & 1F.1 & 221 & $\begin{array}{l}\text { Designing Wireless Sensor Network Routing on } \\
\text { Agriculture Area Using The LEACH Protocol }\end{array}$ \\
\hline Gumilar, Langlang & 3E. 2 & 711 & $\begin{array}{l}\text { Variations in the Placement of DFIG in the Power } \\
\text { System to Changes of Short Circuit Current }\end{array}$ \\
\hline Gunawan, Dadang & 1E.2 & 182 & $\begin{array}{l}\text { Initial Access in } 5 G \text { mmWave Communication } \\
\text { using Hybrid Genetic Algorithm and Particle } \\
\text { Swarm Optimization }\end{array}$ \\
\hline Gupta, Anju & $2 C .9$ & 445 & $\begin{array}{l}\text { Robust Control Design Procedure and Simulation } \\
\text { of PRES Controller having Phase-Locked } \\
\text { Loop(PLL) control technique in Grid-Tied } \\
\text { Converter }\end{array}$ \\
\hline \multicolumn{4}{|c|}{ H A B C D E F G H I K L M N P Q R T U W X Y Z } \\
\hline Hadikurniawati, Wiwien & $1 C .1$ & 83 & $\begin{array}{l}\text { Performance Comparison of Data Mining } \\
\text { Techniques for Rain Prediction Models in Indonesia }\end{array}$ \\
\hline Halim, Arwin & $2 \mathrm{~A} .4$ & 326 & $\begin{array}{l}\text { Optimization of } S V-k N N C \text { using Silhouette } \\
\text { Coefficient and LMKNN for Stock Price Prediction }\end{array}$ \\
\hline Hamed, Fatima & $1 B .7$ & 68 & $\begin{array}{l}\text { Risk Prediction of Major Depressive Disorder using } \\
\text { Artificial Neural Network }\end{array}$ \\
\hline
\end{tabular}




\begin{tabular}{|c|c|c|c|}
\hline Hamka Ibrahim, Muhammad & $2 C .6$ & 428 & $\begin{array}{l}\text { Design and Development of Bit Error Measurement } \\
\text { using FPGA for Visible Light Communication }\end{array}$ \\
\hline Hanifa, Annisa & 2 C. 6 & 428 & $\begin{array}{l}\text { Design and Development of Bit Error Measurement } \\
\text { using FPGA for Visible Light Communication }\end{array}$ \\
\hline Harintaka, Harintaka & $2 G .5$ & 604 & $\begin{array}{l}\text { Comparison of the Latest DTM with DEM Pleiades } \\
\text { in Monitoring the Dynamic Peatland }\end{array}$ \\
\hline \multirow[t]{2}{*}{ Hartanto, Rudy } & $2 B .1$ & 354 & $\begin{array}{l}\text { The User Experience effect of Applying Floating } \\
\text { Action Button (FAB) into Augmented Reality } \\
\text { Anatomy Cranium Media Learning Prototype }\end{array}$ \\
\hline & $2 \mathrm{G} .3$ & 593 & $\begin{array}{l}\text { Multi-Point Travel Destination Recommendation } \\
\text { System In Yogyakarta Using Hybrid Location } \\
\text { Based Service-Floyd Warshall Method }\end{array}$ \\
\hline Hasibuan, Siti & $1 B .3$ & 52 & $\begin{array}{l}\text { Speaker Recognition Using Mel Frequency Cepstral } \\
\text { Coefficient and Self-Organising Fuzzy Logic }\end{array}$ \\
\hline Hasim, Sitronella & $1 F .8$ & 262 & $\begin{array}{l}\text { Performance Evaluation of Cell-Edge Femtocell } \\
\text { Densely Deployed in OFDMA-Based Macrocellular } \\
\text { Network }\end{array}$ \\
\hline Hastuti, Puji & $2 \mathrm{G} .4$ & 599 & $\begin{array}{l}\text { Application For Detection Of Pedestrian Position } \\
\text { On Zebra Cross }\end{array}$ \\
\hline Hermawan, Tofan & $1 F .3$ & 233 & $\begin{array}{l}\text { Android Forensic Tools Analysis for Unsend Chat } \\
\text { on Social Media }\end{array}$ \\
\hline Hermawati, Hermawati & 3A.1 & 621 & $\begin{array}{l}\text { Facial Expression Recognition and Face } \\
\text { Recognition Using a Convolutional Neural Network }\end{array}$ \\
\hline Herumurti, Darlis & 3 C. 2 & 661 & $\begin{array}{l}\text { The Use of Pre and Post Processing to Enhance } \\
\text { Mandible Segmentation using Active Contours on } \\
\text { Dental Panoramic Radiography Images }\end{array}$ \\
\hline Hery, Hery & $1 C .1$ & 89 & $\begin{array}{l}\text { Website Design for Locating Tuna Fishing Spot } \\
\text { Using Nä̈ve Bayes and SVM Based on VMS Data } \\
\text { on Indonesian Sea }\end{array}$ \\
\hline Hidayat, Firhat & 1E.6 & 203 & $\begin{array}{l}\text { Network Attack Detection System Using Filter- } \\
\text { based Feature Selection and SVM }\end{array}$ \\
\hline \multirow[t]{3}{*}{ Hidayat, Risanuri } & 3B. 1 & 642 & $\begin{array}{l}\text { Comparison of Feature Extraction for Speaker } \\
\text { Identification System }\end{array}$ \\
\hline & $1 F .5$ & 245 & $\begin{array}{l}\text { Single Snapshot-Spatial Compressive Beamforming } \\
\text { for Azimuth Estimation and Backscatter } \\
\text { Reconstruction }\end{array}$ \\
\hline & $1 B .3$ & 52 & $\begin{array}{l}\text { Speaker Recognition Using Mel Frequency Cepstral } \\
\text { Coefficient and Self-Organising Fuzzy Logic }\end{array}$ \\
\hline Hidayat, Taufik & 2G.7 & 615 & $\begin{array}{l}\text { Validation of Information Technology Value Model } \\
\text { for Petroleum Industry }\end{array}$ \\
\hline
\end{tabular}




\begin{tabular}{|c|c|c|c|}
\hline & $2 G .6$ & 609 & $\begin{array}{l}\text { Model Development of Information Technology } \\
\text { Value for Downstream Petroleum Industry }\end{array}$ \\
\hline & $2 F .1$ & 534 & $\begin{array}{l}\text { Effect of Android and Social Media User Growth on } \\
\text { the Financial Technology Lending Borrowers and } \\
\text { its Financing }\end{array}$ \\
\hline Hikmah, Awaliyatul & $1 C .2$ & 94 & $\begin{array}{l}\text { The Best Parameter Tuning on RNN Layers for } \\
\text { Indonesian Text Classification }\end{array}$ \\
\hline Hikmarika, Hera & 3A.1 & 621 & $\begin{array}{l}\text { Facial Expression Recognition and Face } \\
\text { Recognition Using a Convolutional Neural Network }\end{array}$ \\
\hline \multirow[t]{2}{*}{ Hikmaturokhman, Alfin } & $1 G .3$ & 278 & $\begin{array}{l}5 G \text { New Radio (NR) Network Planning at } \\
\text { Frequency 2,6 GHz in The Gold Triangle Area of } \\
\text { Jakarta }\end{array}$ \\
\hline & $1 \mathrm{G} .2$ & 272 & $\begin{array}{l}\text { Techno-Economic 5G New Radio Planning at } 26 \\
\text { GHz Frequency in Pulogadung Industrial Area }\end{array}$ \\
\hline Hilmizen, Naufal & $1 \mathrm{~A} .6$ & 26 & $\begin{array}{l}\text { The Multimodal Transfer Learning for Diagnosing } \\
\text { COVID-19 Pneumonia from Chest CT-Scan and X- } \\
\text { Ray Images }\end{array}$ \\
\hline Hindrayani, Kartika & $2 \mathrm{~A} .7$ & 344 & $\begin{array}{l}\text { Indonesian Stock Price Prediction including } \\
\text { Covid19 Era Using Decision Tree Regression }\end{array}$ \\
\hline Husin, Zaenal & 3A.1 & 621 & $\begin{array}{l}\text { Facial Expression Recognition and Face } \\
\text { Recognition Using a Convolutional Neural Network }\end{array}$ \\
\hline Hutami, Augustine & $2 \mathrm{E} .2$ & 499 & $\begin{array}{l}\text { Supervised Deep Learning for Thyroid Nodules } \\
\text { Classification Based on Margin Characteristic }\end{array}$ \\
\hline \multicolumn{4}{|c|}{ I A B C D E F G H I K L M N O P Q R S T U W X Y Z } \\
\hline Iftadi, Irwan & $2 \mathrm{C} .6$ & 428 & $\begin{array}{l}\text { Design and Development of Bit Error Measurement } \\
\text { using FPGA for Visible Light Communication }\end{array}$ \\
\hline \multirow[t]{2}{*}{ Indriawati, Katherin } & $1 G .6$ & 295 & $\begin{array}{l}\text { Particle Filter Based Speed Estimator for Speed } \\
\text { Sensorless Control in Induction Motor }\end{array}$ \\
\hline & $1 \mathrm{G} .7$ & 301 & $\begin{array}{l}\text { Disturbance Observer-Based Speed Estimator for } \\
\text { Controlling Speed Sensorless Induction Motor }\end{array}$ \\
\hline Irawan, Arif & $2 B .8$ & 394 & $\begin{array}{l}\text { Smart Safe Prototype Based Internet of Things } \\
\text { (IoT) with Face and Fingerprint Recognition }\end{array}$ \\
\hline Irnawan, Roni & $2 \mathrm{C} .1$ & 400 & $\begin{array}{l}\text { Minimization of Power Losses through Optimal } \\
\text { Placement and Sizing from Solar Power and Battery } \\
\text { Energy Storage System in Distribution System }\end{array}$ \\
\hline Iskandar, Nur Muhamad & $1 G .1$ & 267 & $\begin{array}{l}\text { A Combination of Defected Ground Structure and } \\
\text { Line Resonator for Mutual Coupling Reduction }\end{array}$ \\
\hline Isnandar, Suroso & $2 \mathrm{C} .5$ & 423 & $\begin{array}{l}\text { Analysis of Performance Index in Transmission } \\
\text { Expansion Planning of Sulawesi's Electricity } \\
\text { System }\end{array}$ \\
\hline
\end{tabular}




\begin{tabular}{|c|c|c|c|}
\hline \multirow[t]{3}{*}{ Istikmal, Istikmal } & $1 \mathrm{D} .3$ & 140 & $\begin{array}{l}\text { Experimental Security Analysis for Fake eNodeB } \\
\text { Attack on LTE Network }\end{array}$ \\
\hline & $1 \mathrm{D} .6$ & 158 & $\begin{array}{l}\text { Performance Analysis FSR and DSR Routing } \\
\text { Protocol in VANET with V2V and V2I Models }\end{array}$ \\
\hline & 2B.8 & 394 & $\begin{array}{l}\text { Smart Safe Prototype Based Internet of Things } \\
\text { (IoT) with Face and Fingerprint Recognition }\end{array}$ \\
\hline \multicolumn{4}{|c|}{ J A B C D E F G H I K L M N O P Q R T U W X Y Z } \\
\hline Jati Anggoro, Wisang & 1E.7 & 209 & $\begin{array}{l}\text { Development of Smart Energy Meter Based on } \\
\text { LoRaWAN in Campus Area }\end{array}$ \\
\hline Jatmiko, Wisnu & $2 \mathrm{E} .5$ & 520 & $\begin{array}{l}\text { Indonesian Traffic Sign Recognition For Advanced } \\
\text { Driver Assistent (ADAS) Using YOLOv4 }\end{array}$ \\
\hline Julzarika, Atriyon & $2 \mathrm{G} .5$ & 604 & $\begin{array}{l}\text { Comparison of the Latest DTM with DEM Pleiades } \\
\text { in Monitoring the Dynamic Peatland }\end{array}$ \\
\hline \multicolumn{4}{|c|}{ K A B C D E F G I J K L M N P Q R S T U X Y Z } \\
\hline \multirow[t]{2}{*}{ Kamirul, Kamirul } & $1 G .4$ & 284 & $\begin{array}{l}\text { Modification of } 2.2 \text { GHz S-Band Rectangular Patch } \\
\text { Microstrip Antenna using Truncated Corner Method } \\
\text { for Satellite Applications }\end{array}$ \\
\hline & $1 G .5$ & 289 & $\begin{array}{l}\text { Design of Optimal Satellite Constellation for } \\
\text { Indonesian Regional Navigation System based on } \\
\text { GEO and GSO Satellites }\end{array}$ \\
\hline Karna, Nyoman & $1 \mathrm{D} .3$ & 140 & $\begin{array}{l}\text { Experimental Security Analysis for Fake eNodeB } \\
\text { Attack on LTE Network }\end{array}$ \\
\hline Karo, Ferdinanta & $1 G .3$ & 278 & $\begin{array}{l}5 G \text { New Radio (NR) Network Planning at } \\
\text { Frequency 2,6 GHz in The Gold Triangle Area of } \\
\text { Jakarta }\end{array}$ \\
\hline Khairunnisa, Syifa & $2 \mathrm{D} .5$ & 471 & $\begin{array}{l}\text { Removing Noise, Reducing dimension, and } \\
\text { Weighting Distance to Enhance } k \text {-Nearest Neighbors } \\
\text { for Diabetes Classification }\end{array}$ \\
\hline Komarudin, Udin & $2 F .5$ & 551 & $\begin{array}{l}\text { Development of Temperature and Humidity } \\
\text { Control System in Internet-of-Things based Oyster } \\
\text { Mushroom Cultivation }\end{array}$ \\
\hline Kouty, Shreyus & $2 C .8$ & 439 & $\begin{array}{l}\text { Multilayer Secure Hardware Network Stack using } \\
\text { FPGA }\end{array}$ \\
\hline Krisnadi, Dion & $1 C .1$ & 89 & $\begin{array}{l}\text { Website Design for Locating Tuna Fishing Spot } \\
\text { Using Nä̈ve Bayes and SVM Based on VMS Data } \\
\text { on Indonesian Sea }\end{array}$ \\
\hline Kristiani, Eveline & $2 \mathrm{G} .1$ & 577 & $\begin{array}{l}\text { Case Study: AppDynamics Application as Business } \\
\text { Intelligence to Support Digital Business Operations } \\
\text { at PT PGD }\end{array}$ \\
\hline
\end{tabular}




\begin{tabular}{|c|c|c|c|}
\hline Kunang, Yesi & $1 \mathrm{D} .4$ & 146 & $\begin{array}{l}\text { Improving Classification Attacks in IOT Intrusion } \\
\text { Detection System using Bayesian Hyperparameter } \\
\text { Optimization }\end{array}$ \\
\hline Kurniawati, Yulia Ery & $1 B .1$ & 42 & $\begin{array}{l}\text { Papaya Disease Detection Using Fuzzy Naïve Bayes } \\
\text { Classifier }\end{array}$ \\
\hline Kusnandar, Kusnandar & $2 \mathrm{~F} .5$ & 551 & $\begin{array}{l}\text { Development of Temperature and Humidity } \\
\text { Control System in Internet-of-Things based Oyster } \\
\text { Mushroom Cultivation }\end{array}$ \\
\hline \multicolumn{4}{|c|}{ L A B C DEF G H I K L M N O QR S T U W X Y Z } \\
\hline Lagunov, Alexey & $3 \mathrm{E} .1$ & 705 & $\begin{array}{l}\text { Features of the Use of Solar Panels at Low } \\
\text { Temperatures in the Arctic }\end{array}$ \\
\hline Lee, HoonJae & $1 \mathrm{E} .3$ & 187 & $\begin{array}{l}\text { TwoChain: Leveraging Blockchain and Smart } \\
\text { Contract for Two Factor Authentication }\end{array}$ \\
\hline Lee, Sang-Gon & $1 \mathrm{E} .3$ & 187 & $\begin{array}{l}\text { TwoChain: Leveraging Blockchain and Smart } \\
\text { Contract for Two Factor Authentication }\end{array}$ \\
\hline Lin, Haitao & $1 \mathrm{~A} .2$ & 12 & $\begin{array}{l}\text { Distributed Alternating Direction Multiplier } \\
\text { Method Based on Optimized Topology and Nodes } \\
\text { Selection Strategy }\end{array}$ \\
\hline Lubis, Ainul & $2 B .3$ & 365 & $\begin{array}{l}\text { Proximity-based COVID-19 Contact Tracing } \\
\text { System Devices for Locally Problems Solution }\end{array}$ \\
\hline Lukas, Samuel & $1 C .1$ & 89 & $\begin{array}{l}\text { Website Design for Locating Tuna Fishing Spot } \\
\text { Using Naïve Bayes and SVM Based on VMS Data } \\
\text { on Indonesian Sea }\end{array}$ \\
\hline \multicolumn{4}{|c|}{ M A B C D E F G H I K L M NOP QR S T U X Y Z } \\
\hline Mahamad, Abd Kadir & $2 B .4$ & 371 & $\begin{array}{l}\text { Development of The Personnel Monitoring System } \\
\text { Using Mobile Application and Real-Time Database } \\
\text { During the COVDD19 Pandemic }\end{array}$ \\
\hline \multirow[t]{3}{*}{ Mahardiko, Rahutomo } & $2 \mathrm{G} .7$ & 615 & $\begin{array}{l}\text { Validation of Information Technology Value Model } \\
\text { for Petroleum Industry }\end{array}$ \\
\hline & $2 \mathrm{G} .6$ & 609 & $\begin{array}{l}\text { Model Development of Information Technology } \\
\text { Value for Downstream Petroleum Industry }\end{array}$ \\
\hline & $2 F .1$ & 534 & $\begin{array}{l}\text { Effect of Android and Social Media User Growth on } \\
\text { the Financial Technology Lending Borrowers and } \\
\text { its Financing }\end{array}$ \\
\hline Mahersatillah, Andi & $3 \mathrm{D} .2$ & 688 & $\begin{array}{l}\text { Unstructured Road Detection and Steering Assist } \\
\text { Based on HSV Color Space Segmentation for } \\
\text { Autonomous Car }\end{array}$ \\
\hline Mahfiz, Syiti & $2 \mathrm{D} .8$ & 488 & $\begin{array}{l}\text { Aspect-based Opinion Mining on Beauty Product } \\
\text { Reviews }\end{array}$ \\
\hline
\end{tabular}




\begin{tabular}{|c|c|c|c|}
\hline Manik, Lindung & 3A. 2 & 627 & $\begin{array}{l}\text { Stemming Javanese: Another Adaptation of the } \\
\text { Nazief-Adriani Algorithm }\end{array}$ \\
\hline Mardhotillah, Rinda & $2 \mathrm{E} .4$ & 514 & $\begin{array}{l}\text { Speaker Recognition For Digital Forensic Audio } \\
\text { Analysis Using Support Vector Machine }\end{array}$ \\
\hline Masngut, Ibnu & $2 B .2$ & 360 & $\begin{array}{l}\text { Development and Implementation of Kalman Filter } \\
\text { for IoT Sensors: Towards a Better Precision } \\
\text { Agriculture }\end{array}$ \\
\hline Maulana, Eka & $1 \mathrm{E} .7$ & 209 & $\begin{array}{l}\text { Development of Smart Energy Meter Based on } \\
\text { LoRaWAN in Campus Area }\end{array}$ \\
\hline Mawaldi, Ikbal & $1 D .3$ & 140 & $\begin{array}{l}\text { Experimental Security Analysis for Fake eNodeB } \\
\text { Attack on LTE Network }\end{array}$ \\
\hline Mootha, Siddartha & $3 \mathrm{E} .4$ & 721 & $\begin{array}{l}\text { A Stacking Ensemble of Multi Layer Perceptrons to } \\
\text { Predict Online Shoppers' Purchasing Intention }\end{array}$ \\
\hline Mubarok, Husein & $2 B .5$ & 377 & $\begin{array}{l}\text { Prototype Design of IoT (Internet of Things)-based } \\
\text { Load Monitoring System }\end{array}$ \\
\hline Muchtar, Akhyar & $2 C .4$ & 418 & $\begin{array}{l}\text { The Single Tuned Filter Planning to Mitigate } \\
\text { Harmonic Pollution in Radial Distribution Network } \\
\text { Using Particle Swarm Optimization }\end{array}$ \\
\hline Muchtar, Kahlil & 2E. 3 & 509 & $\begin{array}{l}\text { Convolutional Network and Moving Object } \\
\text { Analysis for Vehicle Detection in Highway } \\
\text { Surveillance Videos }\end{array}$ \\
\hline Muflikhah, Lailil & $1 \mathrm{~A} .8$ & 37 & $\begin{array}{l}\text { Prediction of Liver Cancer Based on DNA Sequence } \\
\text { Using Ensemble Method }\end{array}$ \\
\hline Muharram, Muh. & 2D.4 & 467 & $\begin{array}{l}\text { Firefly Algorithm-based Optimization of Base } \\
\text { Transceiver Station Placement }\end{array}$ \\
\hline Mujahidin, Irfan & 1A. 2 & 7 & $\begin{array}{l}\text { Blackbox Testing Model Boundary Value of } \\
\text { Mapping Taxonomy Applications and Data } \\
\text { Analysis of Art and Artworks }\end{array}$ \\
\hline Muladi, Muladi & 2B. 4 & 371 & $\begin{array}{l}\text { Development of The Personnel Monitoring System } \\
\text { Using Mobile Application and Real-Time Database } \\
\text { During the COVD19 Pandemic }\end{array}$ \\
\hline Mulyanto, Agus & $2 \mathrm{E} .5$ & 520 & $\begin{array}{l}\text { Indonesian Traffic Sign Recognition For Advanced } \\
\text { Driver Assistent (ADAS) Using YOLOv4 }\end{array}$ \\
\hline Munadi, Rendy & $1 \mathrm{D} .7$ & 164 & $\begin{array}{l}\text { DDoS Attack Detection in Software Defined } \\
\text { Network using Ensemble K-means++ and Random } \\
\text { Forest }\end{array}$ \\
\hline Mungkasi, Sudi & $2 \mathrm{~A} .2$ & 321 & $\begin{array}{l}\text { Some Numerical and Analytical Solutions to an } \\
\text { Enzyme-Substrate Reaction-Diffusion Problem }\end{array}$ \\
\hline Mursanto, Petrus & $2 \mathrm{E} .5$ & 520 & $\begin{array}{l}\text { Indonesian Traffic Sign Recognition For Advanced } \\
\text { Driver Assistent (ADAS) Using YOLOv4 }\end{array}$ \\
\hline
\end{tabular}




\begin{tabular}{|c|c|c|c|}
\hline Murwantara, I Made & $1 \mathrm{C} .1$ & 89 & $\begin{array}{l}\text { Website Design for Locating Tuna Fishing Spot } \\
\text { Using Nä̈ve Bayes and SVM Based on VMS Data } \\
\text { on Indonesian Sea }\end{array}$ \\
\hline \multirow[t]{5}{*}{ Mustika, I Wayan } & $1 \mathrm{E} .5$ & 198 & $\begin{array}{l}\text { Roadside Unit Power Saving using Vehicle } \\
\text { Detection System in Vehicular Ad-hoc Network }\end{array}$ \\
\hline & $1 \mathrm{E} .8$ & 215 & $\begin{array}{l}\text { Performance Enhancement in Macro-Femto } \\
\text { Network Using a Modified Discrete Moth-flame } \\
\text { Optimization Algorithm }\end{array}$ \\
\hline & 1E.7 & 209 & $\begin{array}{l}\text { Development of Smart Energy Meter Based on } \\
\text { LoRaWAN in Campus Area }\end{array}$ \\
\hline & $1 \mathrm{D} .2$ & 135 & $\begin{array}{l}\text { Interference Mitigation in Cognitive Radio Network } \\
\text { Based on Grey Wolf Optimizer Algorithm }\end{array}$ \\
\hline & $2 \mathrm{G} .4$ & 599 & $\begin{array}{l}\text { Application For Detection Of Pedestrian Position } \\
\text { On Zebra Cross }\end{array}$ \\
\hline $\begin{array}{l}\text { Muthchamy Sellamuthu, Karthika } \\
\text { Devi }\end{array}$ & 3E.4 & 721 & $\begin{array}{l}\text { A Stacking Ensemble of Multi Layer Perceptrons to } \\
\text { Predict Online Shoppers' Purchasing Intention }\end{array}$ \\
\hline Muttaqin, Didik & 2D.3 & 463 & $\begin{array}{l}\text { Speech Emotion Detection Using Mel-Frequency } \\
\text { Cepstral Coefficient and Hidden Markov Model }\end{array}$ \\
\hline \multicolumn{4}{|c|}{ A B C D E F G H I J L M N O P Q R S T U W X Y Z } \\
\hline N. Fathee, Hala & $3 \mathrm{~B} .4$ & 655 & $\begin{array}{l}\text { A Robust Iris Segmentation Algorithm Based on } \\
\text { Pupil Region for Visible Wavelength Environments }\end{array}$ \\
\hline Nafi'iyah, Nur & 3 C. 2 & 661 & $\begin{array}{l}\text { The Use of Pre and Post Processing to Enhance } \\
\text { Mandible Segmentation using Active Contours on } \\
\text { Dental Panoramic Radiography Images }\end{array}$ \\
\hline Nagy, Adam & 3A.3 & 632 & $\begin{array}{l}\text { A bio-motivated vision system and artificial neural } \\
\text { network for autonomous } U A V \text { obstacle avoidance }\end{array}$ \\
\hline Najmurrokhman, Asep & $2 \mathrm{~F} .5$ & 551 & $\begin{array}{l}\text { Development of Temperature and Humidity } \\
\text { Control System in Internet-of-Things based Oyster } \\
\text { Mushroom Cultivation }\end{array}$ \\
\hline Nam, Andrew & $1 \mathrm{~A} .1$ & 1 & $\begin{array}{l}\text { Resource-Aware Pareto-Optimal Automated } \\
\text { Machine Learning Platform }\end{array}$ \\
\hline Nasaruddin, Nasaruddin & 2E.3 & 509 & $\begin{array}{l}\text { Convolutional Network and Moving Object } \\
\text { Analysis for Vehicle Detection in Highway } \\
\text { Surveillance Videos }\end{array}$ \\
\hline \multirow[t]{2}{*}{ Nashiruddin, Muhammad Imam } & $1 F .6$ & 251 & $\begin{array}{l}\text { Performance Evaluation of XGS-PON Optical } \\
\text { Network Termination for Enterprise Customer }\end{array}$ \\
\hline & $1 F .4$ & 239 & $\begin{array}{l}\text { Performance Evaluation of IPTV Multicast Service } \\
\text { Testing for XGS-PON Optical Line Termination }\end{array}$ \\
\hline Nasr-Azadani, Mohamad & 1A.1 & 1 & $\begin{array}{l}\text { Resource-Aware Pareto-Optimal Automated } \\
\text { Machine Learning Platform }\end{array}$ \\
\hline
\end{tabular}




\begin{tabular}{|c|c|c|c|}
\hline Nasri, Muhammad & $2 B .1$ & 354 & $\begin{array}{l}\text { The User Experience effect of Applying Floating } \\
\text { Action Button (FAB) into Augmented Reality } \\
\text { Anatomy Cranium Media Learning Prototype }\end{array}$ \\
\hline Nguyen-Quoc, Huy & 2D.1 & 451 & $\begin{array}{l}\text { Gender recognition based on ear images: } a \\
\text { comparative experimental study }\end{array}$ \\
\hline Nivaan, Goldy Valendria & $1 \mathrm{C} .4$ & 106 & $\begin{array}{l}\text { Analytic Predictive of Hepatitis using The } \\
\text { Regression Logic Algorithm }\end{array}$ \\
\hline \multirow[t]{2}{*}{ Noer, Astriany } & $1 G .4$ & 284 & $\begin{array}{l}\text { Modification of } 2.2 \mathrm{GHz} \text { S-Band Rectangular Patch } \\
\text { Microstrip Antenna using Truncated Corner Method } \\
\text { for Satellite Applications }\end{array}$ \\
\hline & $1 G .5$ & 289 & $\begin{array}{l}\text { Design of Optimal Satellite Constellation for } \\
\text { Indonesian Regional Navigation System based on } \\
\text { GEO and GSO Satellites }\end{array}$ \\
\hline NQ, Mohammad Arifin & 3A.2 & 627 & $\begin{array}{l}\text { Stemming Javanese: Another Adaptation of the } \\
\text { Nazief-Adriani Algorithm }\end{array}$ \\
\hline \multirow[t]{2}{*}{ Nugraha, Syechu } & $2 C .3$ & 412 & $\begin{array}{l}\text { Design and Implementation of SVPWM Inverter to } \\
\text { Reduce Total Harmonic Distortion (THD) on Three } \\
\text { Phase Induction Motor Speed Regulation Using } \\
\text { Constant V/F }\end{array}$ \\
\hline & $2 \mathrm{C} .2$ & 406 & $\begin{array}{l}\text { Three Phase Induction Motor Dynamic Speed } \\
\text { Regulation Using IP Controller }\end{array}$ \\
\hline Nugroho, Hanung & 2E. 2 & 499 & $\begin{array}{l}\text { Supervised Deep Learning for Thyroid Nodules } \\
\text { Classification Based on Margin Characteristic }\end{array}$ \\
\hline \multirow[t]{2}{*}{ Nugroho, Lukito } & $2 \mathrm{G} .3$ & 593 & $\begin{array}{l}\text { Multi-Point Travel Destination Recommendation } \\
\text { System In Yogyakarta Using Hybrid Location } \\
\text { Based Service-Floyd Warshall Method }\end{array}$ \\
\hline & $2 \mathrm{G} .4$ & 599 & $\begin{array}{l}\text { Application For Detection Of Pedestrian Position } \\
\text { On Zebra Cross }\end{array}$ \\
\hline Nur, Darfiana & $2 \mathrm{~A} .1$ & 310 & $\begin{array}{l}\text { On Parameter Estimation of Stochastic Delay } \\
\text { Difference Equation using the Two m-delay } \\
\text { Autoregressive Coefficients }\end{array}$ \\
\hline Nurdewanto, B. & 1A.2 & 7 & $\begin{array}{l}\text { Blackbox Testing Model Boundary Value of } \\
\text { Mapping Taxonomy Applications and Data } \\
\text { Analysis of Art and Artworks }\end{array}$ \\
\hline Nurfadillah, Raditya & 2D.2 & 457 & $\begin{array}{l}\text { Benchmarking Explicit Rating Prediction } \\
\text { Algorithms for Cosmetic Products }\end{array}$ \\
\hline Nurlina, Elin & $2 F .5$ & 551 & $\begin{array}{l}\text { Development of Temperature and Humidity } \\
\text { Control System in Internet-of-Things based Oyster } \\
\text { Mushroom Cultivation }\end{array}$ \\
\hline
\end{tabular}




\begin{tabular}{|c|c|c|c|}
\hline Nurmaini, Siti & $1 \mathrm{D} .4$ & 146 & $\begin{array}{l}\text { Improving Classification Attacks in IOT Intrusion } \\
\text { Detection System using Bayesian Hyperparameter } \\
\text { Optimization }\end{array}$ \\
\hline Nurtiyasari, Devi & $3 C .3$ & 667 & $\begin{array}{l}\text { COVID-19 Chest X-Ray Classification Using } \\
\text { Convolutional Neural Network Architectures }\end{array}$ \\
\hline Nurwarsito, Heru & $1 \mathrm{E} .1$ & 176 & $\begin{array}{l}\text { Performance Analysis of Temporally Ordered } \\
\text { Routing Algorithm Protocol and Zone Routing } \\
\text { Protocol On Vehicular Ad-Hoc Network in Urban } \\
\text { Environment }\end{array}$ \\
\hline Nusantara, Damai & $2 \mathrm{C} .5$ & 423 & $\begin{array}{l}\text { Analysis of Performance Index in Transmission } \\
\text { Expansion Planning of Sulawesi's Electricity } \\
\text { System }\end{array}$ \\
\hline \multicolumn{4}{|c|}{ A B C D E F G H I K L M N O P Q R S T W X Y Z } \\
\hline Octarina, Sisca & $2 \mathrm{~A} .1$ & 315 & $\begin{array}{l}\text { The N-Sheet Model in Capacitated Multi-Period } \\
\text { Cutting Stock Problem with Pattern Set-Up Cost }\end{array}$ \\
\hline Oktian, Yustus & $1 \mathrm{E} .3$ & 187 & $\begin{array}{l}\text { TwoChain: Leveraging Blockchain and Smart } \\
\text { Contract for Two Factor Authentication }\end{array}$ \\
\hline Osman, Safaa & $1 B .7$ & 68 & $\begin{array}{l}\text { Risk Prediction of Major Depressive Disorder using } \\
\text { Artificial Neural Network }\end{array}$ \\
\hline \multicolumn{4}{|c|}{ P A B C D E F G H I K L M N O P R T U W X Y Z } \\
\hline Perkasa, Gregorius & $1 \mathrm{D} .2$ & 135 & $\begin{array}{l}\text { Interference Mitigation in Cognitive Radio Network } \\
\text { Based on Grey Wolf Optimizer Algorithm }\end{array}$ \\
\hline Permana, Indra & $2 F .1$ & 534 & $\begin{array}{l}\text { Effect of Android and Social Media User Growth on } \\
\text { the Financial Technology Lending Borrowers and } \\
\text { its Financing }\end{array}$ \\
\hline Permanasari, Adhistya & 2B.1 & 354 & $\begin{array}{l}\text { The User Experience effect of Applying Floating } \\
\text { Action Button (FAB) into Augmented Reality } \\
\text { Anatomy Cranium Media Learning Prototype }\end{array}$ \\
\hline Petho, Mate & 3A.3 & 632 & $\begin{array}{l}\text { A bio-motivated vision system and artificial neural } \\
\text { network for autonomous } U A V \text { obstacle avoidance }\end{array}$ \\
\hline Prakoso, Rahardi & $1 \mathrm{D} .8$ & 170 & $\begin{array}{l}\text { Measurement of Information Security Awareness } \\
\text { Level: A Case Study of Online Transportation } \\
\text { Users }\end{array}$ \\
\hline Pramono, Subuh & $2 C .6$ & 428 & $\begin{array}{l}\text { Design and Development of Bit Error Measurement } \\
\text { using FPGA for Visible Light Communication }\end{array}$ \\
\hline Prasetya, Suisbiyanto & $1 \mathrm{G} .4$ & 284 & $\begin{array}{l}\text { Modification of } 2.2 \text { GHz S-Band Rectangular Patch } \\
\text { Microstrip Antenna using Truncated Corner Method } \\
\text { for Satellite Applications }\end{array}$ \\
\hline Prasetyawan, Purwono & $2 \mathrm{E} .5$ & 520 & $\begin{array}{l}\text { Indonesian Traffic Sign Recognition For Advanced } \\
\text { Driver Assistent (ADAS) Using YOLOv4 }\end{array}$ \\
\hline
\end{tabular}




\begin{tabular}{|c|c|c|c|}
\hline Prasetyo, Wisnu & $2 \mathrm{~A} .8$ & 348 & $\begin{array}{l}\text { Students Academic Performance Prediction with } k \text { - } \\
\text { Nearest Neighbor and C4.5 on SMOTE-balanced } \\
\text { data }\end{array}$ \\
\hline Prasojo, Radityo Eko & $2 \mathrm{D} .2$ & 457 & $\begin{array}{l}\text { Benchmarking Explicit Rating Prediction } \\
\text { Algorithms for Cosmetic Products }\end{array}$ \\
\hline Pratama, Denni & $1 \mathrm{~A} .4$ & 17 & $\begin{array}{l}\text { Comparison of PSO, FA, and BA for Discrete } \\
\text { Optimization Problems }\end{array}$ \\
\hline Pratama, Gilang & 2B. 2 & 360 & $\begin{array}{l}\text { Development and Implementation of Kalman Filter } \\
\text { for IoT Sensors: Towards a Better Precision } \\
\text { Agriculture }\end{array}$ \\
\hline Pratama, Raditya & $2 \mathrm{G} .3$ & 593 & $\begin{array}{l}\text { Multi-Point Travel Destination Recommendation } \\
\text { System In Yogyakarta Using Hybrid Location } \\
\text { Based Service-Floyd Warshall Method }\end{array}$ \\
\hline Pratama, Yogaswara & $2 \mathrm{G} .1$ & 577 & $\begin{array}{l}\text { Case Study: AppDynamics Application as Business } \\
\text { Intelligence to Support Digital Business Operations } \\
\text { at PT PGD }\end{array}$ \\
\hline Pratiwi, Melati & $3 C .4$ & 677 & $\begin{array}{l}\text { Classification of Customer Actions on Digital } \\
\text { Money Transactions on PaySim Mobile Money } \\
\text { Simulator using Probabilistic Neural Network } \\
\text { (PNN) Algorithm }\end{array}$ \\
\hline Priyadi, Ardyono & 3E.3 & 716 & $\begin{array}{l}\text { Energy Management Efficiency and Stability Using } \\
\text { Passive Filter in Standalone Photovoltaic Sudden } \\
\text { Cloud Condition }\end{array}$ \\
\hline Priyadi, Yudi & $2 \mathrm{~A} .5$ & 332 & $\begin{array}{l}\text { Extraction Dependency Based on Evolutionary } \\
\text { Requirement Using Natural Language Processing }\end{array}$ \\
\hline \multirow[t]{2}{*}{ Priyambodo, Tri } & 1F.1 & 221 & $\begin{array}{l}\text { Designing Wireless Sensor Network Routing on } \\
\text { Agriculture Area Using The LEACH Protocol }\end{array}$ \\
\hline & $1 \mathrm{D} .1$ & 129 & $\begin{array}{l}\text { Real-time Testing on Improved Data Transmission } \\
\text { Security in the Industrial Control System }\end{array}$ \\
\hline Prutphongs, Ponsuda & $2 \mathrm{G} .2$ & 588 & $\begin{array}{l}\text { Decision Support System for Power Plant } \\
\text { Improvement Investment Using Life-Cycle Cost }\end{array}$ \\
\hline Pujianto, Utomo & $2 \mathrm{~A} .8$ & 348 & $\begin{array}{l}\text { Students Academic Performance Prediction with } k \text { - } \\
\text { Nearest Neighbor and C4.5 on SMOTE-balanced } \\
\text { data }\end{array}$ \\
\hline \multirow[t]{2}{*}{ Purnomo, Hindriyanto } & 1F.7 & 257 & $\begin{array}{l}\text { Detection of Sensor Node-less Area Using A Genetic } \\
\text { Algorithm for Wireless Sensor Network }\end{array}$ \\
\hline & 3D.4 & 700 & $\begin{array}{l}\text { A Modified Deep Convolutional Network for Covid- } \\
19 \text { detection based on chest X-ray images }\end{array}$ \\
\hline Purwanto, Era & $2 C .3$ & 412 & $\begin{array}{l}\text { Design and Implementation of SVPWM Inverter to } \\
\text { Reduce Total Harmonic Distortion (THD) on Three }\end{array}$ \\
\hline
\end{tabular}




\begin{tabular}{|c|c|c|c|}
\hline & & & $\begin{array}{l}\text { Phase Induction Motor Speed Regulation Using } \\
\text { Constant V/F }\end{array}$ \\
\hline & $2 \mathrm{C} .2$ & 406 & $\begin{array}{l}\text { Three Phase Induction Motor Dynamic Speed } \\
\text { Regulation Using IP Controller }\end{array}$ \\
\hline Purwanto, Yudha & $1 \mathrm{D} .7$ & 164 & $\begin{array}{l}\text { DDoS Attack Detection in Software Defined } \\
\text { Network using Ensemble K-means++ and Random } \\
\text { Forest }\end{array}$ \\
\hline Puspita, Fitri Maya & $2 F .5$ & 556 & $\begin{array}{l}\text { Modification of Wireless Reverse Charging Scheme } \\
\text { with Bundling Optimization Issues }\end{array}$ \\
\hline Puspitasari, Novianti & $2 \mathrm{D} .7$ & 482 & $\begin{array}{l}\text { Dayak Onion (Eleutherine palmifolia (L) Merr) as } \\
\text { An Alternative Treatment in Early Detection of } \\
\text { Dental Caries using Certainty Factor }\end{array}$ \\
\hline Putra, Agfianto & $1 \mathrm{D.1}$ & 129 & $\begin{array}{l}\text { Real-time Testing on Improved Data Transmission } \\
\text { Security in the Industrial Control System }\end{array}$ \\
\hline $\begin{array}{l}\text { Putranto, Bambang Purnomosidi } \\
\text { Dwi }\end{array}$ & $2 B .6$ & 383 & $\begin{array}{l}\text { A Comparative Study of Java and Kotlin for } \\
\text { Android Mobile Application Development }\end{array}$ \\
\hline \multirow[t]{2}{*}{ Putranto, Lesnanto Multa } & $2 \mathrm{C} .5$ & 423 & $\begin{array}{l}\text { Analysis of Performance Index in Transmission } \\
\text { Expansion Planning of Sulawesi's Electricity } \\
\text { System }\end{array}$ \\
\hline & $2 \mathrm{C} .1$ & 400 & $\begin{array}{l}\text { Minimization of Power Losses through Optimal } \\
\text { Placement and Sizing from Solar Power and Battery } \\
\text { Energy Storage System in Distribution System }\end{array}$ \\
\hline Putri, Andi & $2 \mathrm{C} .4$ & 418 & $\begin{array}{l}\text { The Single Tuned Filter Planning to Mitigate } \\
\text { Harmonic Pollution in Radial Distribution Network } \\
\text { Using Particle Swarm Optimization }\end{array}$ \\
\hline \multicolumn{4}{|c|}{ Q A B C D E F G H J K L M N P QR S T U X Y Z } \\
\hline Qomariyah, Nunung Nurul & $1 C .8$ & 123 & $\begin{array}{l}\text { Predicting User Preferences with XGBoost Learning } \\
\text { to Rank Method }\end{array}$ \\
\hline \multirow[t]{2}{*}{ Qudsi, Ony } & $2 \mathrm{C} .3$ & 412 & $\begin{array}{l}\text { Design and Implementation of SVPWM Inverter to } \\
\text { Reduce Total Harmonic Distortion (THD) on Three } \\
\text { Phase Induction Motor Speed Regulation Using } \\
\text { Constant V/F }\end{array}$ \\
\hline & $2 \mathrm{C} .2$ & 406 & $\begin{array}{l}\text { Three Phase Induction Motor Dynamic Speed } \\
\text { Regulation Using IP Controller }\end{array}$ \\
\hline \multicolumn{4}{|l|}{ 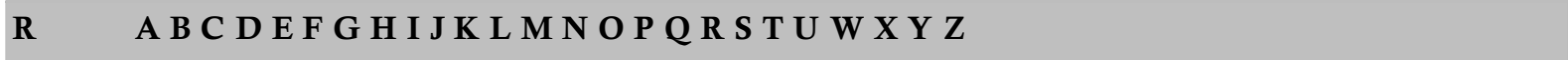 } \\
\hline R., Christiono & $2 \mathrm{C} .4$ & 418 & $\begin{array}{l}\text { The Single Tuned Filter Planning to Mitigate } \\
\text { Harmonic Pollution in Radial Distribution Network } \\
\text { Using Particle Swarm Optimization }\end{array}$ \\
\hline Rachmawaty, Dina & $1 G .2$ & 272 & $\begin{array}{l}\text { Techno-Economic 5G New Radio Planning at } 26 \\
\text { GHz Frequency in Pulogadung Industrial Area }\end{array}$ \\
\hline
\end{tabular}




\begin{tabular}{|c|c|c|c|}
\hline Rahayu, Eny Sukani & $1 F .5$ & 245 & $\begin{array}{l}\text { Single Snapshot-Spatial Compressive Beamforming } \\
\text { for Azimuth Estimation and Backscatter } \\
\text { Reconstruction }\end{array}$ \\
\hline Ramadhan, Firdiansyah & 2E.1 & 494 & $\begin{array}{l}\text { Royale Heroes: A Unique RTS Game Using Deep } \\
\text { Reinforcement Learning-based Autonomous } \\
\text { Movement }\end{array}$ \\
\hline Ramadhani, Kurniawan & 2E.3 & 505 & $\begin{array}{l}\text { Combined Firefly Algorithm-Random Forest to } \\
\text { Classify Autistic Spectrum Disorders }\end{array}$ \\
\hline Ratchagit, Manlika & $2 \mathrm{~A} .1$ & 310 & $\begin{array}{l}\text { On Parameter Estimation of Stochastic Delay } \\
\text { Difference Equation using the Two m-delay } \\
\text { Autoregressive Coefficients }\end{array}$ \\
\hline Rianti, Desi & $1 G .2$ & 272 & $\begin{array}{l}\text { Techno-Economic } 5 \text { G New Radio Planning at } 26 \\
\text { GHz Frequency in Pulogadung Industrial Area }\end{array}$ \\
\hline Ridhatama, Hasbi & $2 F .5$ & 551 & $\begin{array}{l}\text { Development of Temperature and Humidity } \\
\text { Control System in Internet-of-Things based Oyster } \\
\text { Mushroom Cultivation }\end{array}$ \\
\hline Rifa'i, Nanang & $1 \mathrm{G} .7$ & 301 & $\begin{array}{l}\text { Disturbance Observer-Based Speed Estimator for } \\
\text { Controlling Speed Sensorless Induction Motor }\end{array}$ \\
\hline \multirow[t]{2}{*}{ Rifadil, Mochammad } & 2 C. 3 & 412 & $\begin{array}{l}\text { Design and Implementation of SVPWM Inverter to } \\
\text { Reduce Total Harmonic Distortion (THD) on Three } \\
\text { Phase Induction Motor Speed Regulation Using } \\
\text { Constant V/F }\end{array}$ \\
\hline & 2 C. 2 & 406 & $\begin{array}{l}\text { Three Phase Induction Motor Dynamic Speed } \\
\text { Regulation Using IP Controller }\end{array}$ \\
\hline Riyadi, E. Hadiyono & $1 D .1$ & 129 & $\begin{array}{l}\text { Real-time Testing on Improved Data Transmission } \\
\text { Security in the Industrial Control System }\end{array}$ \\
\hline Riyantoko, Prismahardi & 2A.7 & 344 & $\begin{array}{l}\text { Indonesian Stock Price Prediction including } \\
\text { Covid19 Era Using Decision Tree Regression }\end{array}$ \\
\hline Robbi, Niki & $1 \mathrm{D} .2$ & 135 & $\begin{array}{l}\text { Interference Mitigation in Cognitive Radio Network } \\
\text { Based on Grey Wolf Optimizer Algorithm }\end{array}$ \\
\hline Romadhony, Ade & 2D.8 & 488 & $\begin{array}{l}\text { Aspect-based Opinion Mining on Beauty Product } \\
\text { Reviews }\end{array}$ \\
\hline \multirow[t]{2}{*}{ Rosadi, Dedi } & $3 C .3$ & 667 & $\begin{array}{l}\text { COVID-19 Chest X-Ray Classification Using } \\
\text { Convolutional Neural Network Architectures }\end{array}$ \\
\hline & 1B. 2 & 48 & $\begin{array}{l}\text { Prediction of forest fire occurrence in peatlands } \\
\text { using machine learning approaches }\end{array}$ \\
\hline Rosselina, Linda & 1F.3 & 233 & $\begin{array}{l}\text { Android Forensic Tools Analysis for Unsend Chat } \\
\text { on Social Media }\end{array}$ \\
\hline Ruldeviyani, Yova & 2G.1 & 577 & $\begin{array}{l}\text { Case Study: AppDynamics Application as Business } \\
\text { Intelligence to Support Digital Business Operations } \\
\text { at PT PGD }\end{array}$ \\
\hline
\end{tabular}




\begin{tabular}{|l|l|l|l|}
\hline & $1 \mathrm{D.8}$ & $170 \begin{array}{l}\text { Measurement of Information Security Awareness } \\
\text { Level: A Case Study of Online Transportation } \\
\text { Users }\end{array}$ \\
\hline Rusdiyanto, Dian & $2 \mathrm{~F} .7$ & 567 & $\begin{array}{l}\text { Comparison Of Eight Elements Array Structure } \\
\text { Design For Coastal Surveillance Radar }\end{array}$ \\
\hline Rusli, Muhammad & $2 \mathrm{C.3}$ & 412 & $\begin{array}{l}\text { Design and Implementation of SVPWM Inverter to } \\
\text { Reduce Total Harmonic Distortion (THD) on Three } \\
\text { Phase Induction Motor Speed Regulation Using } \\
\text { Constant V/F }\end{array}$ \\
\hline
\end{tabular}

\section{S A B C DEFG I J K L M N OP QR S T U W X Y Z}

S, Subaryono

Sa'adah, Siti

Safitri, Eristya

Sahmoud, Shaaban

Samudera, Satriya

Santoso, Fian

3D.4

Sarjiya, Sarjiya

2C. 5

2A. 7

3B. 4

2C. 2

3C. 4

A. 7

2

Sarwinda, Devvi

$1 \mathrm{~A} .6$

Sasmito, Adityan

$1 C .5$

Sediyono, Eko
604 Comparison of the Latest DTM with DEM Pleiades in Monitoring the Dynamic Peatland

32 Prediction of Gross Domestic Product (GDP) in Indonesia Using Deep Learning Algorithm

677 Classification of Customer Actions on Digital Money Transactions on PaySim Mobile Money Simulator using Probabilistic Neural Network (PNN) Algorithm

344 Indonesian Stock Price Prediction including Covid19 Era Using Decision Tree Regression

655 A Robust Iris Segmentation Algorithm Based on Pupil Region for Visible Wavelength Environments

406 Three Phase Induction Motor Dynamic Speed Regulation Using IP Controller

700 A Modified Deep Convolutional Network for Covid19 detection based on chest $X$-ray images

423 Analysis of Performance Index in Transmission Expansion Planning of Sulawesi's Electricity System

400 Minimization of Power Losses through Optimal Placement and Sizing from Solar Power and Battery Energy Storage System in Distribution System

26 The Multimodal Transfer Learning for Diagnosing COVID-19 Pneumonia from Chest CT-Scan and XRay Images

111 Comparison of The Classification Data Mining Methods to Identify Civil Servants in Indonesian Social Insurance Company

257 Detection of Sensor Node-less Area Using A Genetic Algorithm for Wireless Sensor Network 


\begin{tabular}{|c|c|c|c|}
\hline Sendari, Siti & $2 B .4$ & 371 & $\begin{array}{l}\text { Development of The Personnel Monitoring System } \\
\text { Using Mobile Application and Real-Time Database } \\
\text { During the COVD19 Pandemic }\end{array}$ \\
\hline Setianingsih, Casi & $2 \mathrm{E} .4$ & 514 & $\begin{array}{l}\text { Speaker Recognition For Digital Forensic Audio } \\
\text { Analysis Using Support Vector Machine }\end{array}$ \\
\hline Setiawan, Florentinus Budi & 2E.7 & 529 & $\begin{array}{l}\text { Center of Gravity Method for Finding Center of } \\
\text { Laser Beam Projection on Landslide Measurement }\end{array}$ \\
\hline Setijadi, Eko & 1G.1 & 267 & $\begin{array}{l}\text { A Combination of Defected Ground Structure and } \\
\text { Line Resonator for Mutual Coupling Reduction }\end{array}$ \\
\hline Setya Budi, Avian Lukman & 3E.3 & 716 & $\begin{array}{l}\text { Energy Management Efficiency and Stability Using } \\
\text { Passive Filter in Standalone Photovoltaic Sudden } \\
\text { Cloud Condition }\end{array}$ \\
\hline Severin, Ionuț-Cristian & 3C. 3 & 672 & $\begin{array}{l}\text { The Head Posture System Based on } 3 \text { Inertial } \\
\text { Sensors and Machine Learning Models: Offline } \\
\text { Analyze }\end{array}$ \\
\hline Shadieq, Nuur & $1 B .6$ & 62 & $\begin{array}{l}\text { Leveraging Side Information to Anime } \\
\text { Recommender System using Deep learning }\end{array}$ \\
\hline Siahaan, Daniel & $2 \mathrm{~A} .5$ & 332 & $\begin{array}{l}\text { Extraction Dependency Based on Evolutionary } \\
\text { Requirement Using Natural Language Processing }\end{array}$ \\
\hline Simbolon, Josua & $1 G .6$ & 295 & $\begin{array}{l}\text { Particle Filter Based Speed Estimator for Speed } \\
\text { Sensorless Control in Induction Motor }\end{array}$ \\
\hline Sinaga, Frans & $2 \mathrm{~A} .4$ & 326 & $\begin{array}{l}\text { Optimization of SV-kNNC using Silhouette } \\
\text { Coefficient and LMKNN for Stock Price Prediction }\end{array}$ \\
\hline Sirait, Pahala & $2 \mathrm{~A} .4$ & 326 & $\begin{array}{l}\text { Optimization of } S V-k N N C \text { using Silhouette } \\
\text { Coefficient and LMKNN for Stock Price Prediction }\end{array}$ \\
\hline Siregar, Faisal & $1 B .8$ & 73 & $\begin{array}{l}\text { Hybrid Method for Flower Classification in High } \\
\text { Intra-class Variation }\end{array}$ \\
\hline Siswantoro, Joko & 3D.1 & 682 & $\begin{array}{l}\text { Fruits Classification from Image using MPEG-7 } \\
\text { Visual Descriptors and Extreme Learning Machine }\end{array}$ \\
\hline Siswantoro, Muhammad & 3D.1 & 682 & $\begin{array}{l}\text { Fruits Classification from Image using MPEG-7 } \\
\text { Visual Descriptors and Extreme Learning Machine }\end{array}$ \\
\hline Soeprijanto, Adi & 3E.3 & 716 & $\begin{array}{l}\text { Energy Management Efficiency and Stability Using } \\
\text { Passive Filter in Standalone Photovoltaic Sudden } \\
\text { Cloud Condition }\end{array}$ \\
\hline \multirow[t]{2}{*}{ Solihah, Nomarhinta } & 1F.6 & 251 & $\begin{array}{l}\text { Performance Evaluation of XGS-PON Optical } \\
\text { Network Termination for Enterprise Customer }\end{array}$ \\
\hline & 1F.4 & 239 & $\begin{array}{l}\text { Performance Evaluation of IPTV Multicast Service } \\
\text { Testing for XGS-PON Optical Line Termination }\end{array}$ \\
\hline
\end{tabular}




\begin{tabular}{|c|c|c|c|}
\hline Sonalitha, Elta & $1 \mathrm{~A} .2$ & 7 & $\begin{array}{l}\text { Blackbox Testing Model Boundary Value of } \\
\text { Mapping Taxonomy Applications and Data } \\
\text { Analysis of Art and Artworks }\end{array}$ \\
\hline Sridhar, Sashank & $3 \mathrm{E} .4$ & 721 & $\begin{array}{l}\text { A Stacking Ensemble of Multi Layer Perceptrons to } \\
\text { Predict Online Shoppers' Purchasing Intention }\end{array}$ \\
\hline Stiawan, Deris & $1 \mathrm{D} .4$ & 146 & $\begin{array}{l}\text { Improving Classification Attacks in IOT Intrusion } \\
\text { Detection System using Bayesian Hyperparameter } \\
\text { Optimization }\end{array}$ \\
\hline Suban, Ignasius & $1 C .3$ & 100 & $\begin{array}{l}\text { Influence Distribution Training Data on } \\
\text { Performance Supervised Machine Learning } \\
\text { Algorithms }\end{array}$ \\
\hline Subchan, Subchan & $1 G .8$ & 306 & $\begin{array}{l}\text { Ship Heading Control Using Nonlinear Model } \\
\text { Predictive Control }\end{array}$ \\
\hline Subriadi, Apol & $2 F .2$ & 539 & $\begin{array}{l}\text { Consumer Behavior in Social Commerce Adoption: } \\
\text { Systematic Literature Review }\end{array}$ \\
\hline Sudaryanto, Arif & $2 C .3$ & 412 & $\begin{array}{l}\text { Design and Implementation of SVPWM Inverter to } \\
\text { Reduce Total Harmonic Distortion (THD) on Three } \\
\text { Phase Induction Motor Speed Regulation Using } \\
\text { Constant V/F }\end{array}$ \\
\hline Sudiharto, Indhana & 1C.7 & 117 & $\begin{array}{l}\text { Implementation of Maximum Power Point } \\
\text { Tracking on PV System using Artificial Bee Colony } \\
\text { Algorithm }\end{array}$ \\
\hline Sugianto, Sugianto & $2 \mathrm{~A} .6$ & 338 & $\begin{array}{l}\text { Multivariate Time Series Forecasting Based Cloud } \\
\text { Computing For Consumer Price Index Using Deep } \\
\text { Learning Algorithms }\end{array}$ \\
\hline Sulistiadi, Wahyu & $2 F .6$ & 562 & $\begin{array}{l}\text { Measuring Instagram Activity and Engagement } \\
\text { Rate of Hospital: A Comparison Before and During } \\
\text { COVID-19 Pandemic }\end{array}$ \\
\hline Sulistiyono, Mulia & $1 C .2$ & 94 & $\begin{array}{l}\text { The Best Parameter Tuning on RNN Layers for } \\
\text { Indonesian Text Classification }\end{array}$ \\
\hline Sulistyo, Selo & 1E.5 & 198 & $\begin{array}{l}\text { Roadside Unit Power Saving using Vehicle } \\
\text { Detection System in Vehicular Ad-hoc Network }\end{array}$ \\
\hline Sultoni, Arif & $2 F .8$ & 572 & $\begin{array}{l}\text { Implementation of Fuzzy-PID Based MPPT for } \\
\text { Stand Alone } 1.75 \mathrm{kWP} P V \text { System }\end{array}$ \\
\hline Sumadi, Fauzi & $1 \mathrm{D} .5$ & 152 & $\begin{array}{l}\text { Comparative Analysis of DDoS Detection } \\
\text { Techniques Based on Machine Learning in } \\
\text { OpenFlow Network }\end{array}$ \\
\hline Sumiharto, Raden & 1F.1 & 221 & $\begin{array}{l}\text { Designing Wireless Sensor Network Routing on } \\
\text { Agriculture Area Using The LEACH Protocol }\end{array}$ \\
\hline
\end{tabular}




\begin{tabular}{|c|c|c|c|}
\hline \multirow[t]{2}{*}{ Suprapto, Bhakti } & 1D.4 & 146 & $\begin{array}{l}\text { Improving Classification Attacks in IOT Intrusion } \\
\text { Detection System using Bayesian Hyperparameter } \\
\text { Optimization }\end{array}$ \\
\hline & 3A.1 & 621 & $\begin{array}{l}\text { Facial Expression Recognition and Face } \\
\text { Recognition Using a Convolutional Neural Network }\end{array}$ \\
\hline \multirow[t]{2}{*}{ Supriyanto, Eko } & $1 B .8$ & 79 & $\begin{array}{l}\text { Personality Dimensions Classification with EEG } \\
\text { Analysis using Support Vector Machine }\end{array}$ \\
\hline & $1 B .7$ & 68 & $\begin{array}{l}\text { Risk Prediction of Major Depressive Disorder using } \\
\text { Artificial Neural Network }\end{array}$ \\
\hline Suryanto, Yohan & 1F.3 & 233 & $\begin{array}{l}\text { Android Forensic Tools Analysis for Unsend Chat } \\
\text { on Social Media }\end{array}$ \\
\hline Susanto, Misfa & $1 F .8$ & 262 & $\begin{array}{l}\text { Performance Evaluation of Cell-Edge Femtocell } \\
\text { Densely Deployed in OFDMA-Based Macrocellular } \\
\text { Network }\end{array}$ \\
\hline Sussi, Sussi & $1 D .6$ & 158 & $\begin{array}{l}\text { Performance Analysis FSR and DSR Routing } \\
\text { Protocol in VANET with V2V and V2I Models }\end{array}$ \\
\hline Sutivong, Daricha & $2 \mathrm{G} .2$ & 588 & $\begin{array}{l}\text { Decision Support System for Power Plant } \\
\text { Improvement Investment Using Life-Cycle Cost }\end{array}$ \\
\hline Suwadi, Suwadi & 1E.4 & 192 & $\begin{array}{l}\text { Performance Enhancement of Multi-User Key } \\
\text { Extraction Scheme (MKES) Based on Imperfect } \\
\text { Signal Reciprocity }\end{array}$ \\
\hline \multirow[t]{9}{*}{ Suyanto, Suyanto } & $2 \mathrm{D} .4$ & 467 & $\begin{array}{l}\text { Firefly Algorithm-based Optimization of Base } \\
\text { Transceiver Station Placement }\end{array}$ \\
\hline & 2E.1 & 494 & $\begin{array}{l}\text { Royale Heroes: A Unique RTS Game Using Deep } \\
\text { Reinforcement Learning-based Autonomous } \\
\text { Movement }\end{array}$ \\
\hline & $1 \mathrm{~A} .4$ & 17 & $\begin{array}{l}\text { Comparison of PSO, FA, and BA for Discrete } \\
\text { Optimization Problems }\end{array}$ \\
\hline & 2E.6 & 525 & $\begin{array}{l}\text { Text-Independent Speaker Identification Using } \\
\text { PCA-SVM Model }\end{array}$ \\
\hline & 2D.3 & 463 & $\begin{array}{l}\text { Speech Emotion Detection Using Mel-Frequency } \\
\text { Cepstral Coefficient and Hidden Markov Model }\end{array}$ \\
\hline & $1 \mathrm{~A} .5$ & 21 & $\begin{array}{l}\text { PSO-Learned Artificial Neural Networks for } \\
\text { Activity Recognition }\end{array}$ \\
\hline & 2E. 3 & 505 & $\begin{array}{l}\text { Combined Firefly Algorithm-Random Forest to } \\
\text { Classify Autistic Spectrum Disorders }\end{array}$ \\
\hline & 3B. 3 & 650 & $\begin{array}{l}\text { Detection of Multi-Class Glaucoma Using Active } \\
\text { Contour Snakes and Support Vector Machine }\end{array}$ \\
\hline & $2 \mathrm{D} .6$ & 476 & $\begin{array}{l}\text { Topic-Based Tweet Clustering for Public Figures } \\
\text { Using Ant Clustering }\end{array}$ \\
\hline
\end{tabular}




\begin{tabular}{|c|c|c|c|}
\hline & $2 \mathrm{D} .5$ & 471 & $\begin{array}{l}\text { Removing Noise, Reducing dimension, and } \\
\text { Weighting Distance to Enhance } k \text {-Nearest Neighbors } \\
\text { for Diabetes Classification }\end{array}$ \\
\hline & 3B.2 & 646 & $\begin{array}{l}\text { Speech Gender Classification Using Bidirectional } \\
\text { Long Short Term Memory }\end{array}$ \\
\hline Suyanto, Yohanes & 1F.1 & 221 & $\begin{array}{l}\text { Designing Wireless Sensor Network Routing on } \\
\text { Agriculture Area Using The LEACH Protocol }\end{array}$ \\
\hline \multicolumn{4}{|c|}{ T A B C D E F G H J K L M OP QR S T U X Y Z } \\
\hline Taheri, Sahar & $1 B .8$ & 79 & $\begin{array}{l}\text { Personality Dimensions Classification with EEG } \\
\text { Analysis using Support Vector Machine }\end{array}$ \\
\hline Taufani, Agusta & 2A.8 & 348 & $\begin{array}{l}\text { Students Academic Performance Prediction with } k \text { - } \\
\text { Nearest Neighbor and C4.5 on SMOTE-balanced } \\
\text { data }\end{array}$ \\
\hline Truong Hoang, Vinh & 2D.1 & 451 & $\begin{array}{l}\text { Gender recognition based on ear images: } a \\
\text { comparative experimental study }\end{array}$ \\
\hline Tung, Teresa & 1A.1 & 1 & $\begin{array}{l}\text { Resource-Aware Pareto-Optimal Automated } \\
\text { Machine Learning Platform }\end{array}$ \\
\hline
\end{tabular}

\begin{tabular}{|c|c|c|c|}
\hline \multicolumn{4}{|c|}{ U A B C D E F G H I K L M N O P Q R T U W X Y Z } \\
\hline Umam, Mohammad & $1 \mathrm{E} .1$ & 176 & $\begin{array}{l}\text { Performance Analysis of Temporally Ordered } \\
\text { Routing Algorithm Protocol and Zone Routing } \\
\text { Protocol On Vehicular Ad-Hoc Network in Urban } \\
\text { Environment }\end{array}$ \\
\hline Usman, U & $2 \mathrm{C} .4$ & 418 & $\begin{array}{l}\text { The Single Tuned Filter Planning to Mitigate } \\
\text { Harmonic Pollution in Radial Distribution Network } \\
\text { Using Particle Swarm Optimization }\end{array}$ \\
\hline Uyun, Shofwatul & $3 \mathrm{D} .3$ & 694 & $\begin{array}{l}\text { Feature Selection on Magelang Duck Egg Candling } \\
\text { Image Using Variance Threshold Method }\end{array}$ \\
\hline
\end{tabular}

\begin{tabular}{|l|l|r|l|}
\hline W & \multicolumn{1}{|c|}{ A B C D E F G H I J K L M N O P Q R S T U W X Y Z } \\
\hline W, Bambang & $1 \mathrm{G.6}$ & 295 & $\begin{array}{l}\text { Particle Filter Based Speed Estimator for Speed } \\
\text { Sensorless Control in Induction Motor }\end{array}$ \\
\hline & $1 \mathrm{G} .7$ & 301 & $\begin{array}{l}\text { Disturbance Observer-Based Speed Estimator for } \\
\text { Controlling Speed Sensorless Induction Motor }\end{array}$ \\
\hline Wahyudi, Anung & $2 \mathrm{B.7}$ & 389 & $\begin{array}{l}\text { Design and prototype development of internet of } \\
\text { things for greenhouse monitoring system }\end{array}$ \\
\hline Wahyuni, Maria & & 529 & $\begin{array}{l}\text { Center of Gravity Method for Finding Center of } \\
\text { Laser Beam Projection on Landslide Measurement }\end{array}$ \\
\hline Waluyo, Anita & $2 \mathrm{E} .7$ & 583 & $\begin{array}{l}\text { Guided Genetic Algorithm to Solve University } \\
\text { Course Timetabling with Dynamic Time Slot }\end{array}$ \\
\hline
\end{tabular}




\begin{tabular}{|c|c|c|c|}
\hline Wardhani, Shinta Amalia & $2 F .2$ & 539 & $\begin{array}{l}\text { Consumer Behavior in Social Commerce Adoption: } \\
\text { Systematic Literature Review }\end{array}$ \\
\hline Wati, Masna & 2D.7 & 482 & $\begin{array}{l}\text { Dayak Onion (Eleutherine palmifolia (L) Merr) as } \\
\text { An Alternative Treatment in Early Detection of } \\
\text { Dental Caries using Certainty Factor }\end{array}$ \\
\hline Wibisono, Radityo & 2C.7 & 433 & $\begin{array}{l}\text { Optimization Coagulation Process of Water } \\
\text { Treatment Plant Using Neural Network and } \\
\text { Internet of Things (IoT) Communication }\end{array}$ \\
\hline Wibowo, Agung & $1 B .6$ & 62 & $\begin{array}{l}\text { Leveraging Side Information to Anime } \\
\text { Recommender System using Deep learning }\end{array}$ \\
\hline Wibowo, Ferry Wahyu & 1F.7 & 257 & $\begin{array}{l}\text { Detection of Sensor Node-less Area Using A Genetic } \\
\text { Algorithm for Wireless Sensor Network }\end{array}$ \\
\hline Wibowo, Muhammad & $1 \mathrm{~A} .7$ & 32 & $\begin{array}{l}\text { Prediction of Gross Domestic Product (GDP) in } \\
\text { Indonesia Using Deep Learning Algorithm }\end{array}$ \\
\hline Widians, Joan & 2D.7 & 482 & $\begin{array}{l}\text { Dayak Onion (Eleutherine palmifolia (L) Merr) as } \\
\text { An Alternative Treatment in Early Detection of } \\
\text { Dental Caries using Certainty Factor }\end{array}$ \\
\hline Widiyatmoko, Dany & 3A.2 & 627 & $\begin{array}{l}\text { Stemming Javanese: Another Adaptation of the } \\
\text { Nazief-Adriani Algorithm }\end{array}$ \\
\hline Widiyatmoko, Wahyu & 1C.1 & 83 & $\begin{array}{l}\text { Performance Comparison of Data Mining } \\
\text { Techniques for Rain Prediction Models in Indonesia }\end{array}$ \\
\hline Widyawan, Widy & $1 \mathrm{D} .2$ & 135 & $\begin{array}{l}\text { Interference Mitigation in Cognitive Radio Network } \\
\text { Based on Grey Wolf Optimizer Algorithm }\end{array}$ \\
\hline Widyawati, Dewi & 2B.7 & 389 & $\begin{array}{l}\text { Design and prototype development of internet of } \\
\text { things for greenhouse monitoring system }\end{array}$ \\
\hline Wijayanto, Danur & 1F.1 & 221 & $\begin{array}{l}\text { Designing Wireless Sensor Network Routing on } \\
\text { Agriculture Area Using The LEACH Protocol }\end{array}$ \\
\hline Winarno, Edy & 1C.1 & 83 & $\begin{array}{l}\text { Performance Comparison of Data Mining } \\
\text { Techniques for Rain Prediction Models in Indonesia }\end{array}$ \\
\hline Winursito, Anggun & 2B.2 & 360 & $\begin{array}{l}\text { Development and Implementation of Kalman Filter } \\
\text { for IoT Sensors: Towards a Better Precision } \\
\text { Agriculture }\end{array}$ \\
\hline Witono, Timotius & 2F.4 & 545 & $\begin{array}{l}\text { Analysis of Indonesia's Internet Topology Borders } \\
\text { at the Autonomous System Level }\end{array}$ \\
\hline Wiwatanapataphee, Benchawan & 2A.1 & 310 & $\begin{array}{l}\text { On Parameter Estimation of Stochastic Delay } \\
\text { Difference Equation using the Two m-delay } \\
\text { Autoregressive Coefficients }\end{array}$ \\
\hline Wulandari, Eliandri & $1 F .4$ & 239 & $\begin{array}{l}\text { Performance Evaluation of IPTV Multicast Service } \\
\text { Testing for XGS-PON Optical Line Termination }\end{array}$ \\
\hline
\end{tabular}

X A B C D E F G H I K L M N P Q R T U W X Y Z 


\begin{tabular}{|c|c|c|c|}
\hline Xaphakdy, Khampaserth & $1 \mathrm{E} .8$ & 215 & $\begin{array}{l}\text { Performance Enhancement in Macro-Femto } \\
\text { Network Using a Modified Discrete Moth-flame } \\
\text { Optimization Algorithm }\end{array}$ \\
\hline \multicolumn{4}{|c|}{ A B C D E F G H I K L M N O P Q R T U W X Y Z } \\
\hline Yadav, Uma & $2 \mathrm{C} .9$ & 445 & $\begin{array}{l}\text { Robust Control Design Procedure and Simulation } \\
\text { of PRES Controller having Phase-Locked } \\
\text { Loop(PLL) control technique in Grid-Tied } \\
\text { Converter }\end{array}$ \\
\hline Yang, Yao & $1 \mathrm{~A} .1$ & 1 & $\begin{array}{l}\text { Resource-Aware Pareto-Optimal Automated } \\
\text { Machine Learning Platform }\end{array}$ \\
\hline Yazid, Setiadi & $2 \mathrm{~F} .4$ & 545 & $\begin{array}{l}\text { Analysis of Indonesia's Internet Topology Borders } \\
\text { at the Autonomous System Level }\end{array}$ \\
\hline Yudhantomo, Thomas & $2 C .5$ & 423 & $\begin{array}{l}\text { Analysis of Performance Index in Transmission } \\
\text { Expansion Planning of Sulawesi's Electricity } \\
\text { System }\end{array}$ \\
\hline Yudhistiro, Kukuh & $1 \mathrm{~A} .2$ & 7 & $\begin{array}{l}\text { Blackbox Testing Model Boundary Value of } \\
\text { Mapping Taxonomy Applications and Data } \\
\text { Analysis of Art and Artworks }\end{array}$ \\
\hline Yugopuspito, Pujianto & $1 C .1$ & 89 & $\begin{array}{l}\text { Website Design for Locating Tuna Fishing Spot } \\
\text { Using Nä̈ve Bayes and SVM Based on VMS Data } \\
\text { on Indonesian Sea }\end{array}$ \\
\hline Yuliana, Mike & 1E.4 & 192 & $\begin{array}{l}\text { Performance Enhancement of Multi-User Key } \\
\text { Extraction Scheme (MKES) Based on Imperfect } \\
\text { Signal Reciprocity }\end{array}$ \\
\hline Yunanto, Prasti Eko & $2 \mathrm{D} .5$ & 471 & $\begin{array}{l}\text { Removing Noise, Reducing dimension, and } \\
\text { Weighting Distance to Enhance } k \text {-Nearest Neighbors } \\
\text { for Diabetes Classification }\end{array}$ \\
\hline Yusran, Yusran & 3D.2 & 688 & $\begin{array}{l}\text { Unstructured Road Detection and Steering Assist } \\
\text { Based on HSV Color Space Segmentation for } \\
\text { Autonomous Car }\end{array}$ \\
\hline Yusrandi, Yusrandi & $2 \mathrm{~B} .4$ & 371 & $\begin{array}{l}\text { Development of The Personnel Monitoring System } \\
\text { Using Mobile Application and Real-Time Database } \\
\text { During the COVD19 Pandemic }\end{array}$ \\
\hline
\end{tabular}

\section{Z A B C DEF G H I J K L M NOP Q R S T U W X Y Z}

\begin{tabular}{|l|l|l|l|}
\hline Zaeni, Ilham Ari & 2B.4 & 371 & $\begin{array}{l}\text { Development of The Personnel Monitoring System } \\
\text { Using Mobile Application and Real-Time Database } \\
\text { During the COVID19 Pandemic }\end{array}$ \\
\hline Zahara, Soffa & $2 \mathrm{~A} .6$ & 338 & $\begin{array}{l}\text { Multivariate Time Series Forecasting Based Cloud } \\
\text { Computing For Consumer Price Index Using Deep } \\
\text { Learning Algorithms }\end{array}$
\end{tabular}




\begin{tabular}{|c|c|c|c|}
\hline Zainuddin, Zahir & $3 \mathrm{D} .2$ & 688 & $\begin{array}{l}\text { Unstructured Road Detection and Steering Assist } \\
\text { Based on HSV Color Space Segmentation for } \\
\text { Autonomous Car }\end{array}$ \\
\hline Zeng, Shuai & $1 \mathrm{~A} .2$ & 12 & $\begin{array}{l}\text { Distributed Alternating Direction Multiplier } \\
\text { Method Based on Optimized Topology and Nodes } \\
\text { Selection Strategy }\end{array}$ \\
\hline Zsedrovits, Tamas & 3A. 3 & 632 & $\begin{array}{l}\text { A bio-motivated vision system and artificial neural } \\
\text { network for autonomous UAV obstacle avoidance }\end{array}$ \\
\hline Zubair, Anis & $1 \mathrm{~A} .2$ & & $\begin{array}{l}\text { Blackbox Testing Model Boundary Value of } \\
\text { Mapping Taxonomy Applications and Data } \\
\text { Analysis of Art and Artworks }\end{array}$ \\
\hline Zulfira, Fakhira & 3B.3 & 650 & $\begin{array}{l}\text { Detection of Multi-Class Glaucoma Using Active } \\
\text { Contour Snakes and Support Vector Machine }\end{array}$ \\
\hline Zulkifli, Fitri & 1E.7 & 209 & $\begin{array}{l}\text { Development of Smart Energy Meter Based on } \\
\text { LoRaWAN in Campus Area }\end{array}$ \\
\hline
\end{tabular}




\section{Document details - Fruits Classification from Image using MPEG-7 Visual Descriptors and Extreme Learning Machine}

\author{
1 of 1 \\ $\rightarrow$ Export $\Perp$ Download More...>
}

2020 3rd International Seminar on Research of Information Technology and Intelligent Systems, ISRITI 2020

10 December 2020, Article number 9315523, Pages 682-687

3rd International Seminar on Research of Information Technology and Intelligent Systems, ISRITI 2020; STMIK Akakom Yogyakartajalan Raya Janti No 143, Karang Jambe, BanguntapanYogyakarta; Indonesia; 10 December 2020 through ; Category numberCFP20AAH-ART; Code 166521

\section{Fruits Classification from Image using MPEG-7 Visual Descriptors and Extreme Learning Machine(Conference Paper)}

Siswantoro, J., Arwoko, H., Siswantoro, M.Z.F.N.

University of Surabaya, Department of Informatics Engineering, Surabaya, 60293, Indonesia

Abstract

Fruit image classification has several applications and can be used as alternative to traditionally fruit classification performed by human expert. This paper aims to propose fruits classification method from image using extreme learning machine (ELM), MPEG-7 visual descriptors, and principle component analysis (PCA). The optimum parameters of ELM and PCA were determined using grid search optimization. The best classification performance of $97.33 \%$ has been achieved in classifying Indonesian fruit images consisted of 15 classes. By applying the ensemble of ELMs, the classification accuracy was increased to $98.03 \%$. This result shows that the proposed method produces high classification performance. (C) 2020 IEEE.

SciVal Topic Prominence (i)

Topic: Curvelet Transform | Image Classification | Feedforward Neural Networks

Prominence percentile: $\quad 90.981$

(i)

Author keywords

classification extreme learning machine fruit image Indonesian fruit MPEG-7 visual descriptors

Indexed keywords

Engineering controlled terms:

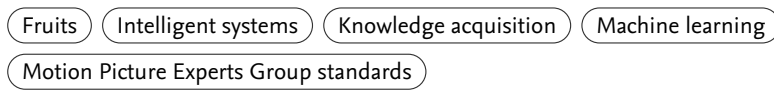

Engineering uncontrolled terms

Classification accuracy Classification methods Classification performance
Extreme learning machine Human expert MPE-7 visual descriptors Optimum parameters
Principle component analysis

Engineering main heading:
Cited by 1 document

Sunaryono, D. , Sarno, R. , Siswantoro, J.

Gradient boosting machines fusion for automatic epilepsy detection from EEG signals based on wavelet features

(2021) Journal of King Saud University - Computer and Information Sciences

View details of this citation

Inform me when this document is cited in Scopus:

Set citation alert Set citation feed $>$ $>$

Related documents

Find more related documents in Scopus based on:

Authors > Keywords >
ISBN: 978-172818406-7

Source Type: Conference Proceeding

Original language: English
DOI: 10.1109/ISRITI51436.2020.9315523

Document Type: Conference Paper

Volume Editors: Wibowo F.W.

Publisher: Institute of Electrical and Electronics Engineers Inc. 
About Scopus

\section{Language}

日本語に切り替える

切换到简体中文

切換到繁體中文

Русский язык

Scopus blog

Scopus API

\section{Customer Service}

Help

Contact us

Privacy matters

ELSEVIER

Terms and conditions $\pi \quad$ Privacy policy $\pi$

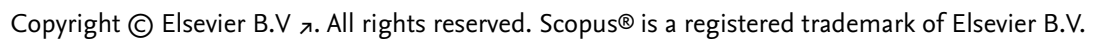

We use cookies to help provide and enhance our service and tailor content. By continuing, you agree to the use of

Q RELX

cookies. 